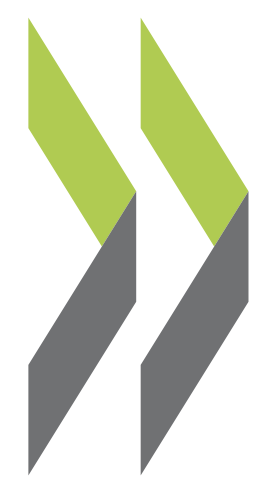

OECD Economics Department Working Papers No. 671

Reforming the Tax System in Korea to Promote Economic Growth and Cope Randall S. Jones with Rapid Population Ageing 
Organisation de Coopération et de Développement Économiques

Organisation for Economic Co-operation and Development

20-Feb-2009

ECONOMICS DEPARTMENT

English - Or. English

REFORMING THE TAX SYSTEM IN KOREA TO PROMOTE ECONOMIC GROWTH AND COPE WITH RAPID POPULATION AGEING

ECONOMICS DEPARTMENT WORKING PAPER No. 671

By Randall S. Jones

All Economics Department Working Papers are available through OECD's internet web site at www.oecd.org/Working_Papers

JT03259986

Document complet disponible sur OLIS dans son format d'origine

Complete document available on OLIS in its original format 


\section{ABSTRACT/RÉSUMÉ}

\section{Reforming the tax system in Korea to promote economic growth and cope with rapid population ageing}

Korea has one of the lowest tax burdens in the OECD area, reflecting its small public sector. However, rapid population ageing will put upward pressure on government spending. The challenge is to meet the long-run need for greater expenditures and tax revenue while sustaining strong economic growth. A pro-growth tax reform implies relying primarily on consumption taxes for additional revenue. There is also scope for raising personal income tax revenue from its current low level by broadening the base by reducing the exemptions for personal income. The planned cuts in the corporate tax rate should be financed at least in part by reductions in tax expenditures. The broadening of direct tax bases would also help finance an expansion of the earned income tax credit to address widening income inequality. In addition, the local tax system should be simplified and reformed to enhance the autonomy of local governments.

This Working Paper relates to the 2008 OECD Economic Surveys: Korea (www.oecd.org/eco/surveys/korea).

JEL classification: H20; H22; H23; H24; H25

Keywords: Taxation; tax reform; Korean tax system; tax wedge; relative poverty; personal income tax; corporate income tax; VAT; property tax; capital gains tax; environmentally-related taxes; tax expenditures; earned income tax credit; local tax system

\section{Réformer le système fiscal en Corée afin de favoriser la croissance économique et de faire face au rapide vieillissement démographique}

La Corée est l'un des pays où la charge fiscale est la plus faible dans la zone de l'OCDE, en raison de la petite taille du secteur public. Cependant, le rapide vieillissement démographique va exercer une pression grandissante sur les finances publiques. La difficulté consiste à répondre au besoin à long terme de dépenses publiques et de recettes fiscales accrues tout en soutenant une vigoureuse expansion économique. Pour qu'une réforme fiscale aide à la croissance, elle doit privilégier les impôts sur la consommation comme source de recettes supplémentaires. Il est aussi possible d'augmenter le produit de l'impôt sur le revenu des personnes physiques, actuellement peu élevé, en élargissant l'assiette grâce à une diminution des exonérations. Les réductions prévues du taux d'imposition des sociétés devraient être financées, en partie du moins, par des compressions de dépenses fiscales. L'élargissement des bases d'imposition directe aiderait aussi à financer une extension du crédit d'impôt sur les revenus d'activité afin de remédier aux inégalités croissantes de revenu. Par ailleurs, le système d'impôts locaux devrait être simplifié et réformé afin de renforcer l'autonomie des collectivités territoriales.

$\mathrm{Ce}$ Document de travail se rapporte à l'Étude économique de l'OCDE de Corée, 2008 (www.oecd.org/eco/etudes/coree).

Classification JEL : H20; H22; H23; H24; H25

Mots clés : Fiscalité; réforme de la taxation; système de taxation coréen; coin fiscal; pauvreté relative; impôt sur le revenu; impôt sur les profits; TVA; taxe foncière; taxes liées à l'environnement; dépenses fiscales; crédit d'impôt sur le revenu d'activités professionnelles; fiscalité locale

Copyright OECD, 2009

Application for permission to reproduce or translate all, or part of, this material should be made to: Head of Publications Service, OECD, 2 rue André-Pascal, 75775 Paris Cedex 16, France. 
TABLE OF CONTENTS

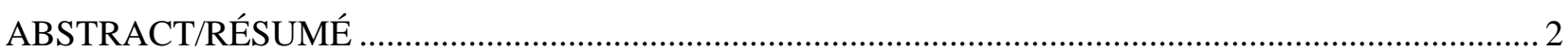

REFORMING THE TAX SYSTEM IN KOREA TO PROMOTE ECONOMIC GROWTH AND COPE

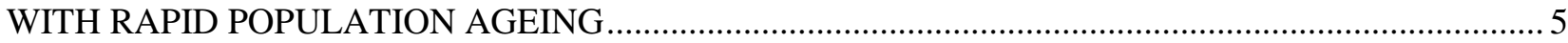

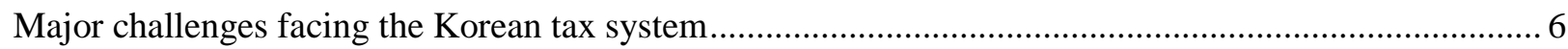

Supporting economic growth in the context of rapid population ageing and globalisation..................... 6

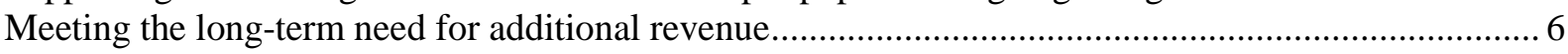

Coping with widening income inequality and rising relative poverty …............................................. 7

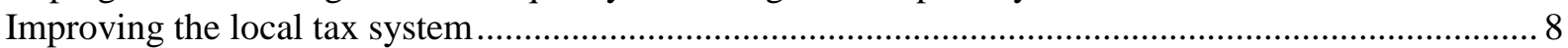

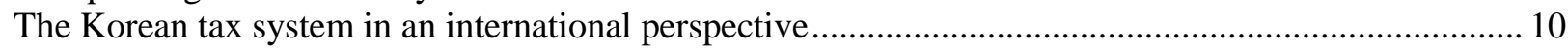

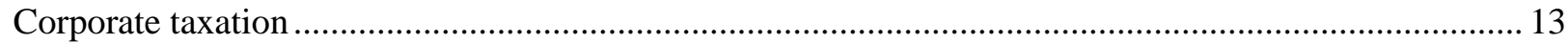

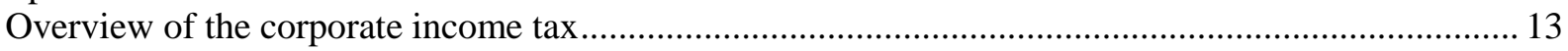

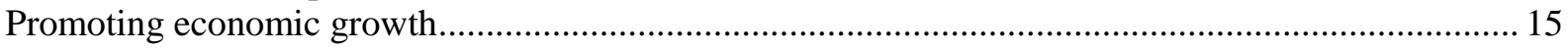

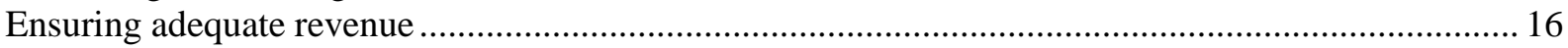

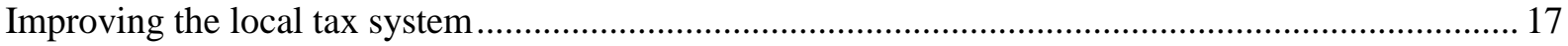

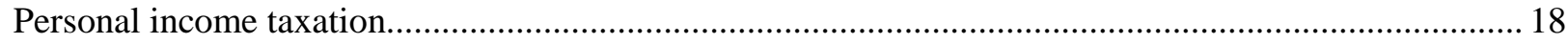

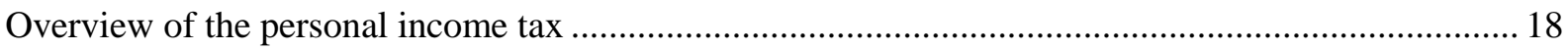

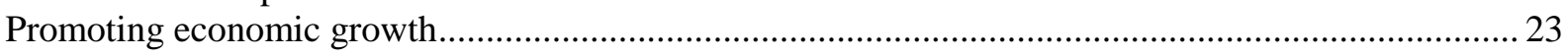

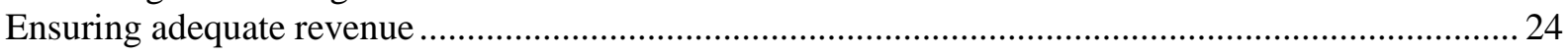

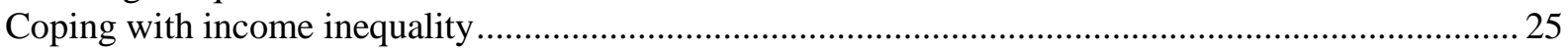

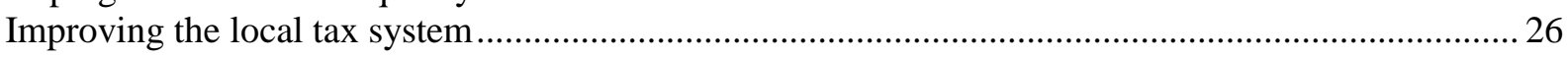

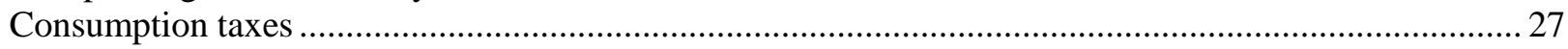

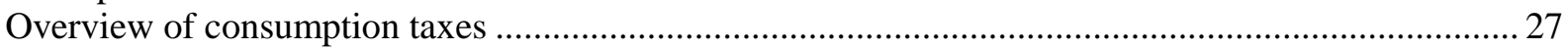

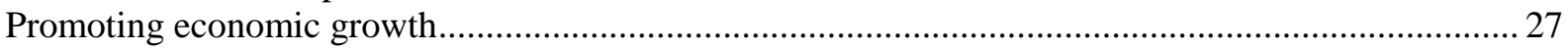

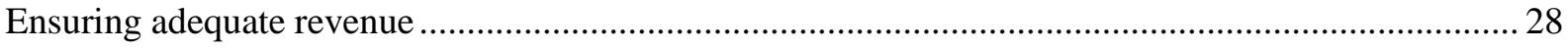

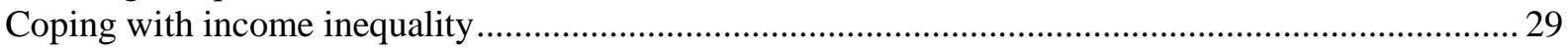

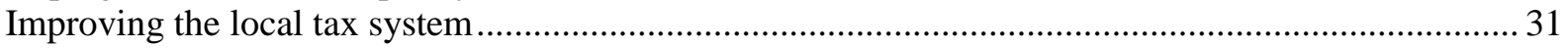

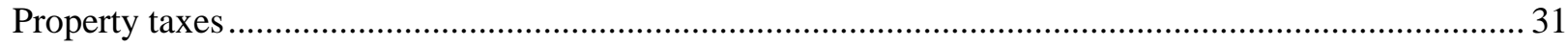

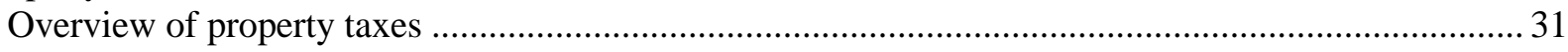

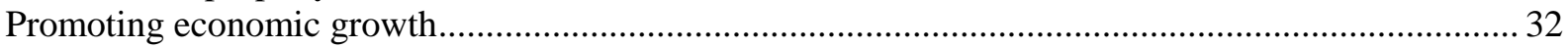

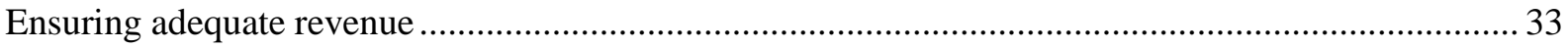

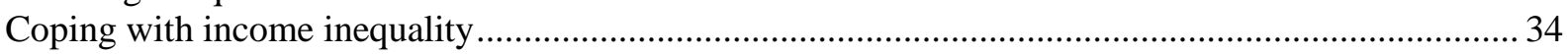

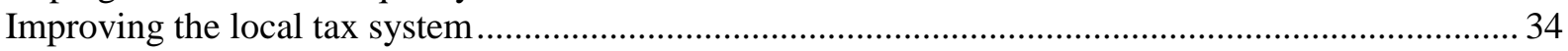

Improving the administration of the tax and social insurance systems .............................................. 35

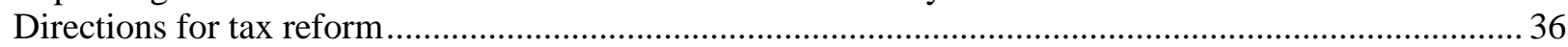

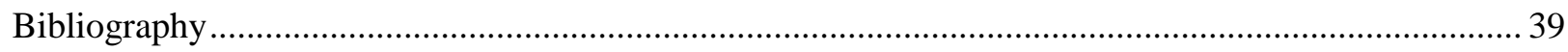

Annex 1. RECENT PROGRESS IN TAX REFORM IN KOREA: A FOLLOW-UP OF THE 2000 OECD ECONOMIC SURVEYS: KOREA. 


\section{Tables}

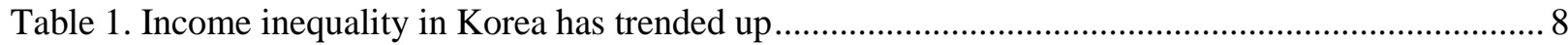

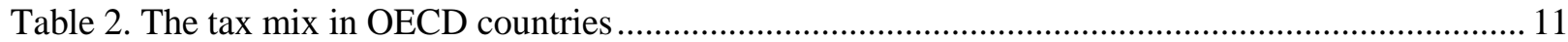

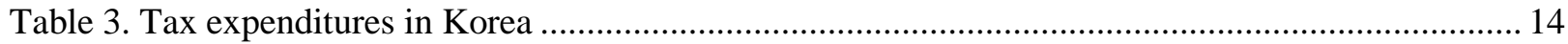

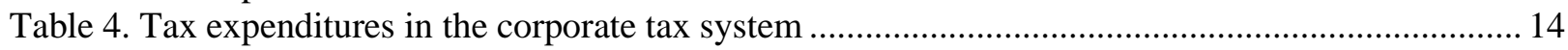

Table 5. Capture ratio of employee and self-employed income.......................................................... 21

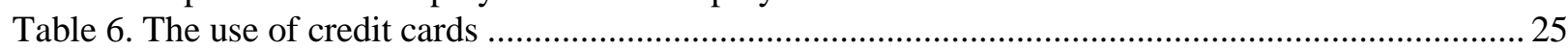

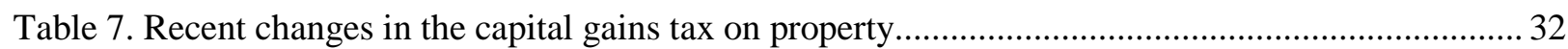

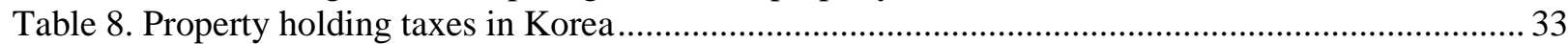

Table 9. Coverage of the social insurance systems by type of worker.................................................... 36

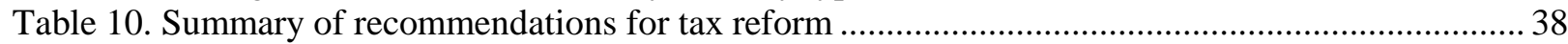

\section{Figures}

Figure 1. The tax burden in Korea is rising toward the OECD average................................................ 5

Figure 2. Public social spending in Korea remains low relative to other OECD countries ...................... 7

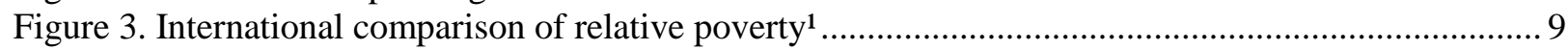

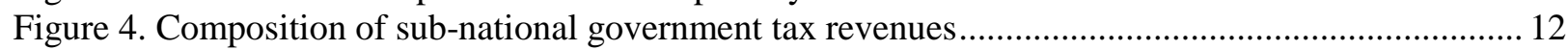

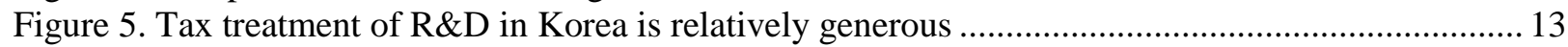

Figure 6. International comparison of statutory corporate income tax rates .......................................... 16

Figure 7. International comparison of corporate tax rates and tax bases ............................................... 18

Figure 8. Top marginal rates and corresponding income threshold ................................................... 19

Figure 9. International comparison of wage income subject to personal income tax.............................. 20

Figure 10. Korea has a relatively low tax wedge on labour .................................................................. 22

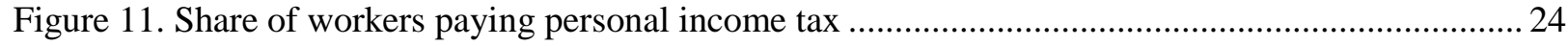

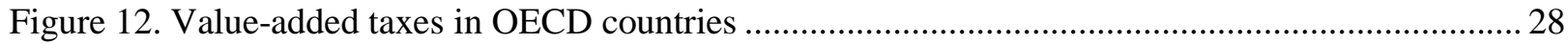

Figure 13. International comparison of environmentally-related taxes............................................... 29

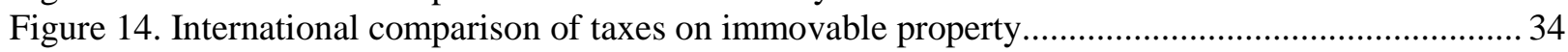

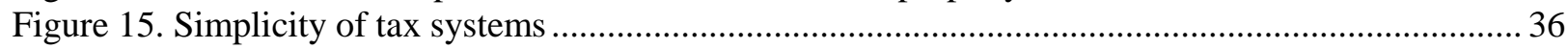

\section{Boxes}

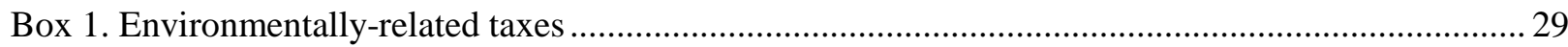


ECO/WKP(2009)12

\title{
REFORMING THE TAX SYSTEM IN KOREA TO PROMOTE ECONOMIC GROWTH AND COPE WITH RAPID POPULATION AGEING
}

\begin{abstract}
Randall S. Jones ${ }^{1}$
1. Korea's tax burden is the second lowest in the OECD area and well below the average of 37\% (Figure 1). However, it is likely to continue rising with rapid population ageing and the development of a social safety net. Korea should take advantage of its sound fiscal position to implement a revenue-neutral tax reform to reduce existing distortions, which will become more harmful as tax pressure mounts in the future. This paper begins by presenting the key challenges facing the Korean tax system - sustaining economic growth, meeting the long-term need for greater revenue, coping with rising income inequality and rising relative poverty and improving the local tax system. It then compares the Korean tax system with other OECD countries and analyses how each of the major taxes can be reformed to meet the key challenges. The paper concludes with recommendations for a comprehensive tax reform, which are summarised in Table 10.
\end{abstract}

Figure 1. The tax burden in Korea is rising toward the OECD average

In per cent of GDP

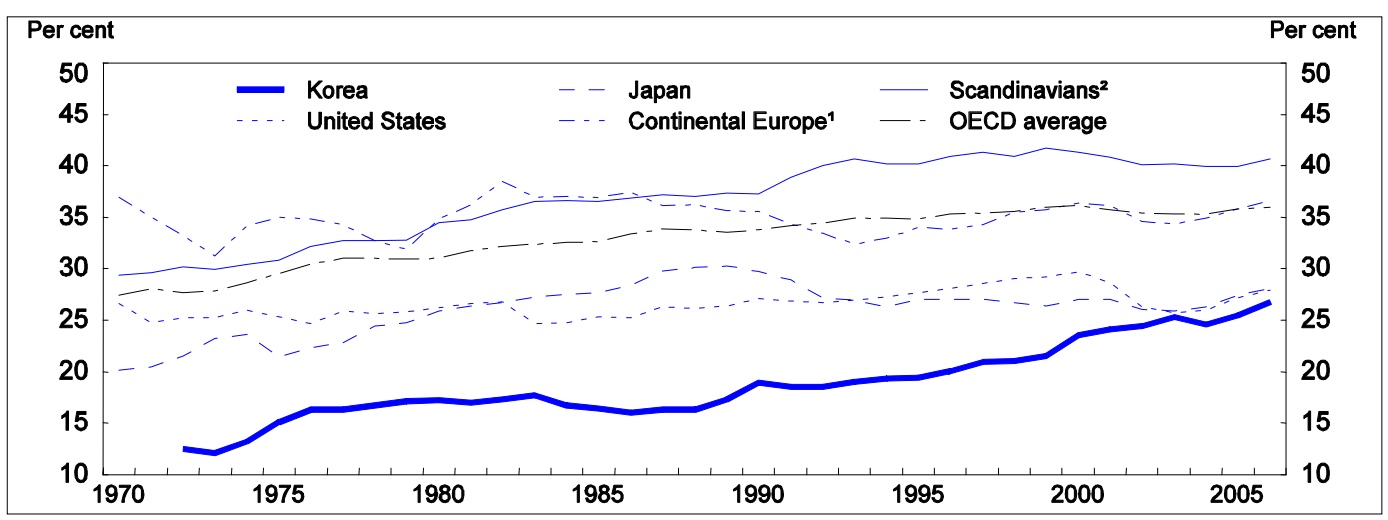

1. France, Germany and Italy.

2. Denmark, Norway and Sweden.

1. Randall S. Jones is head of the Japan/Korea Desk in the Economics Department of the OECD. This paper is based largely on material from the 2008 OECD Economic Surveys: Korea published in December 2008 under the authority of the Economic and Development Review Committee (EDRC). The author would like to thank Andrew Dean, Robert Ford, Christopher Heady, Vincent Koen, Jean-Luc Schneider and Masahiko Tsutsumi for valuable comments on earlier drafts. Special thanks go to Lutécia Daniel for technical assistance and to Nadine Dufour for technical preparation. 
Source: OECD (2008c), Revenue Statistics 1965-2007, OECD, Paris (http://dx.doi.org/10.1787/366725334503).

\section{Major challenges facing the Korean tax system}

\section{Supporting economic growth in the context of rapid population ageing and globalisation}

2. A number of studies, including by the OECD, suggest that raising the overall tax burden can reduce growth. ${ }^{2}$ In addition, the structure of the tax system determines its effect on economic choices and the size of its burden on the economy. In particular, a high tax wedge on labour can price low-skilled persons out of employment, thus reducing labour inputs and discouraging human capital formation, thereby slowing technological progress. Similarly, firms have become more sensitive to cross-country variations in the corporate tax system in the context of globalisation and heightened competition. High tax rates on corporate income make a country less attractive as a location for investment and for reporting profits.

\section{Meeting the long-term need for additional revenue}

3. The small government in Korea reflects limited public social spending, which at $7 \%$ of GDP is the lowest in the OECD area (Figure 2). This is due to the relatively recent launch of a social safety net and Korea's comparatively young population. However, population ageing will put upward spending pressure on the National Pension Scheme, National Health Insurance and Long-Term Care Insurance. According to OECD simulations, Korea's public spending on health and long-term care might rise by 6 to 9 percentage points of GDP by 2050, the largest increase in the OECD area (Oliveira Martins and de la Maisonneuve, 2006), while pension outlays could add another 8 percentage points or more. ${ }^{3}$ In addition, the cost of greater economic co-operation with North Korea may also call for more revenue. Economic deterioration and chronic food shortages in the North during the past decade suggest that the cost of integration may be enormous. Indeed, it is likely to be far heavier than in the case of Germany, given that the population of North Korea is half that of the South, while its per capita income is only about $6 \%$ as large. ${ }^{4}$ Early action on the revenue side would limit the long-term cost from the higher fiscal burden. $^{5}$

2. An increase of about one percentage point in the tax-to-GDP ratio could be associated with a direct reduction of about $0.3 \%$ in output per capita in the long run. If the investment effect is taken into account, the overall reduction would be between $0.6 \%$ and $0.7 \%$ (Bassanini and Scarpetta, 2001). Given that Korea has an exceptionally low tax-to-GDP ratio, the impact may be less.

3. For example, the government's Vision 2030 plan in 2006 projected that public social spending would rise from $6 \%$ of GDP in 2004 to the current OECD average of $21 \%$ by 2030.

4. In contrast, East Germany's population was only a third of the West's at the time of German re-unification, while the per capita income gap was significantly smaller, with that in the East around half of the West.

5. If capital markets perceive that the government has not done enough to address the rising revenue needs, Korea may face lower debt ratings and higher capital costs than otherwise. This may outweigh the negative impact of early increases in tax rates. 
Figure 2. Public social spending in Korea remains low relative to other OECD countries

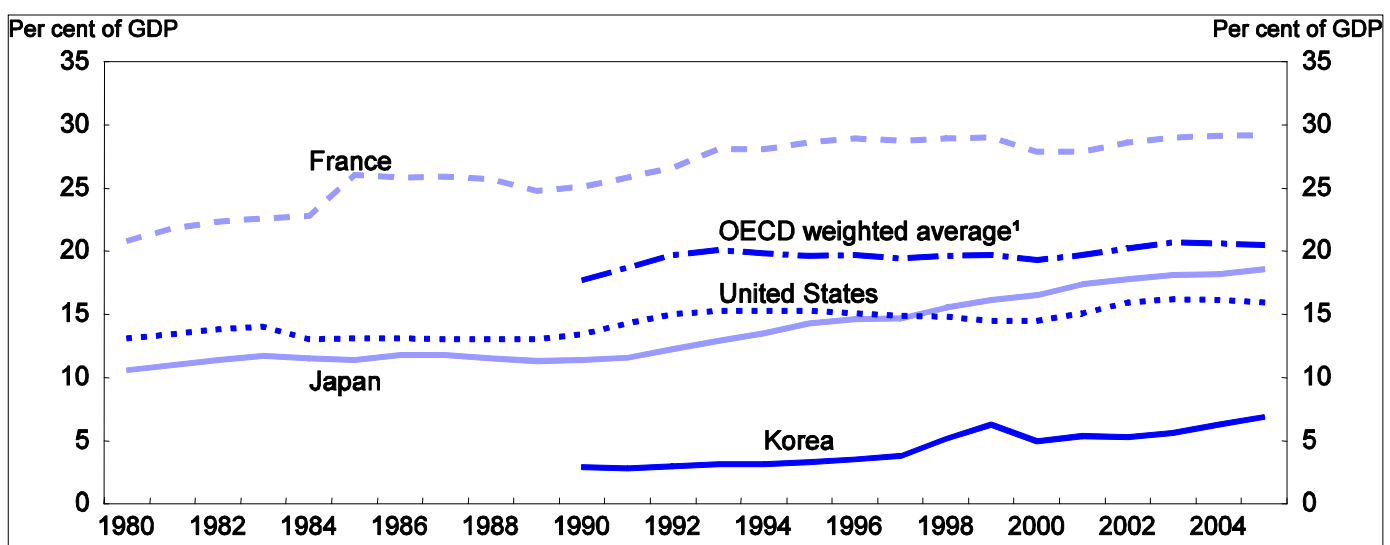

1. The OECD average does not include Hungary and the Slovak Republic for lack of data. The national data are converted to US dollars using 2005 PPP exchange rates.

Source: OECD Social Expenditure Database.

\section{Coping with widening income inequality and rising relative poverty}

4. Korea has experienced a significant rise in income inequality since the 1997 crisis. The ratio of the top income quintile to the bottom one rose from 4.1 in 1997 to 5.7 by 2006 and the Gini coefficient has been trending up (Table 1). The increase in income equality since 1997 is related to the expanding share of non-regular workers, who are paid about $30 \%$ less than regular workers, to more than one-third of employment (see below).

5. Rising inequality has contributed to an increase in the rate of relative poverty to $14.6 \%$ in the mid-2000s, the sixth highest in the OECD area and well above the OECD average of $10.6 \%$ (Figure 3). ${ }^{6}$ As in other countries, population ageing and changes in household structure - more single-person and femaleheaded households - have played a role. However, increased poverty among families headed by a couple accounted for most of the rise, suggesting that higher income inequality was the key factor. High relative poverty also reflects the weak impact of the public sector: the tax and social welfare systems reduced the relative poverty rate only slightly in Korea, from $17.5 \%$ to $14.6 \%$ in the mid-2000s (Panel B). In contrast, the average reduction in the OECD area was 16 percentage points. This suggests a need to use the tax system, together with a further rise in social welfare spending, which has quadrupled in absolute terms since 2000, to reverse these trends. However, strengthening the redistributive function of the tax system needs to be weighed against any negative impact on work incentives, which would reduce potential growth. The challenge is to devise a tax reform that addresses income inequality while minimising the negative impact on growth.

6. Korea National Statistical Office reported a relative poverty rate of $15.2 \%$ for 2005 . 
Table 1. Income inequality in Korea has trended up

For urban salary and wage-earner households 1

\begin{tabular}{lcc}
\hline & Gini coefficient $^{2}$ & Quintile ratio $^{3}$ \\
\cline { 2 - 3 } 1990 & 27.4 & 4.1 \\
1995 & 26.8 & 4.1 \\
1996 & 27.2 & 4.2 \\
1997 & 26.8 & 4.1 \\
1998 & 29.5 & 4.9 \\
1999 & 30.3 & 5.1 \\
2000 & 28.6 & 4.6 \\
2001 & 29.9 & 4.9 \\
2002 & 29.8 & 4.9 \\
2003 & $29.5(30.4)$ & $5.1(5.5)$ \\
2004 & $30.1(31.0)$ & $5.2(5.6)$ \\
2005 & $30.4(31.3)$ & $5.4(5.8)$ \\
2006 & $31.3(32.0)$ & $5.7(6.1)$ \\
\hline
\end{tabular}

1. Data for the entire population, available since 2003, are shown in parentheses.

2. The Gini coefficient is defined as the area between the Lorenz curve (which plots cumulative shares of the population, from richest to poorest, against the cumulative share of income that they receive) and the 45-degree line, taken as a ratio of the whole triangle. The values, which range from 0 in the case of perfect equality to 1 in the case of perfect inequality, are multiplied by 100 to give a range of 0 to 100 .

3. The ratio of the top to the bottom quintile.

Source: Korea National Statistical Office.

\section{Improving the local tax system}

6. Local governments account for about a third of government expenditure, and local educational governments, which are independent of local governments, account for another 15\%. Despite their size, local autonomy is limited, reflecting the legacy of centralised control. The functions of central and local governments are not clearly defined by law and many policy decisions are made at the central level (KRILA, 2007). With tax and non-tax revenues covering only half of their outlays, local governments rely heavily on transfers from the central government. The Local Share Tax, a general grant set at $19.2 \%$ of national "internal tax" revenue (excluding earmarked taxes and customs duties), funds about one-fifth of local expenditure and earmarked grants account for another fifth. The detailed conditions attached to earmarked grants give the central government effective control over a wide array of local policies.

7. Aligning revenues with spending responsibilities would allow local governments to better respond to the preferences of local citizens and help ensure fiscal discipline by making the cost of local services more visible for local taxpayers. Increasing local autonomy, however, is complicated by wide regional variation in the financial autonomy of local jurisdictions. While Seoul is virtually self-financing, $12 \%$ of local governments cannot even fund the salaries of local officials from their own revenues. Reforms that increase local autonomy would therefore tend to boost regional inequality unless they were accompanied by a re-allocation of central government transfers, which would limit local government autonomy. A major challenge, therefore, is to provide local governments with sufficient revenue-raising autonomy to make them accountable to local citizens and encourage fiscal discipline, while ensuring that all have sufficient revenue capacity to provide at least a minimum level of core public services. 
Figure 3. International comparison of relative poverty'

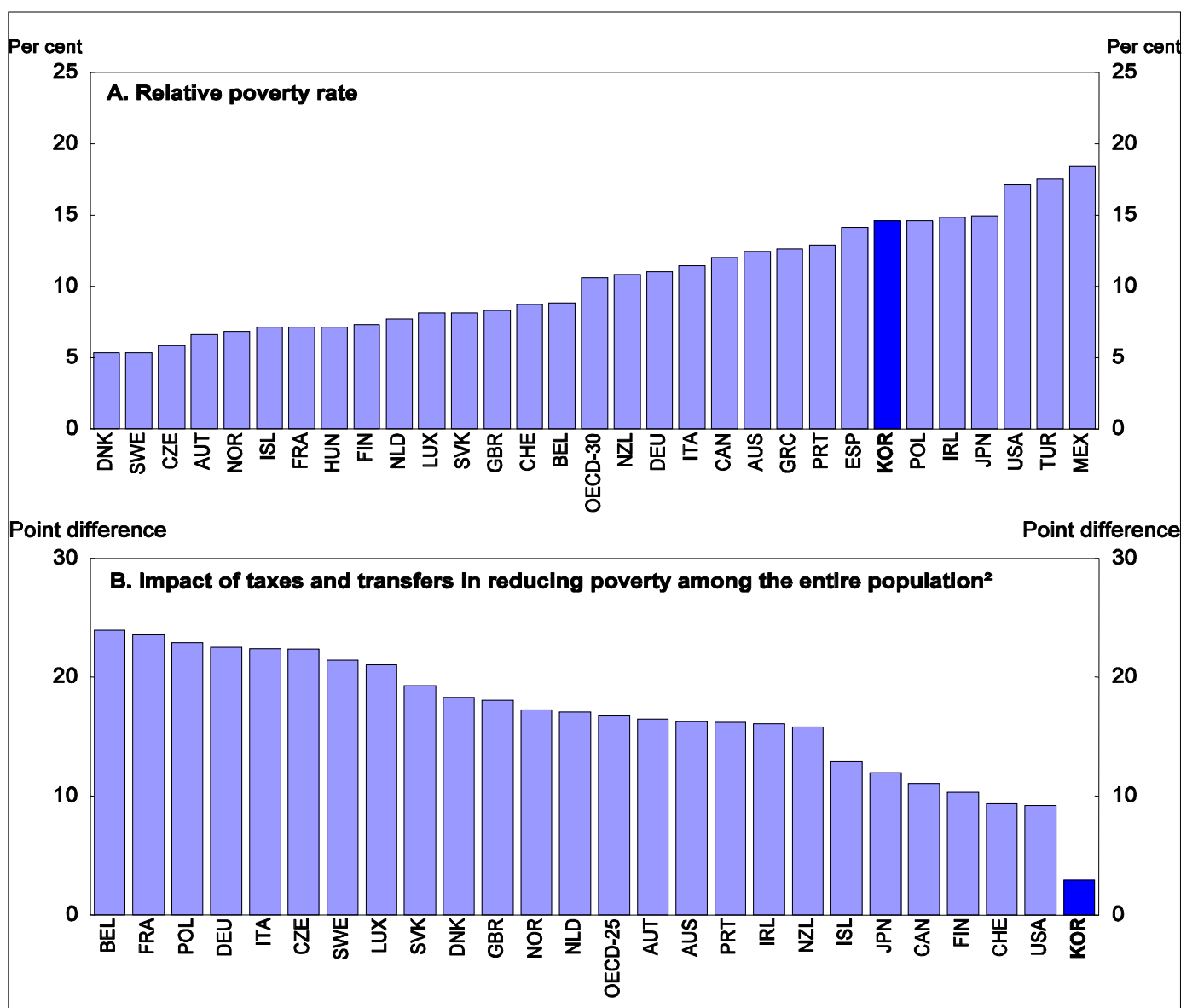

1. entire population.

Poverty rates are defined as the share of individuals with equivalised disposable income below $50 \%$ of the median for the

2. In percentage points. In Korea, taxes and transfers reduced the relative poverty rate from $17.5 \%$ to $14.6 \%$.

Source: OECD (2008b), Growing Unequal? Income Distribution and Poverty in OECD Countries, OECD, Paris.

8. The complicated local tax system, which accounts for about $20 \%$ of total tax revenue, encompasses 16 local taxes, thus compounding compliance and administrative costs. This contrasts with much leaner local tax systems in the Nordic countries for example - at most four local taxes in Finland, Iceland, Norway and Sweden. The local tax system has a number of other weaknesses. First, the heavy reliance on local property transaction taxes acts as a barrier to liquid property markets and efficient land use. Moreover, the volatility of this tax source undermines the stability and predictability of local revenues. Second, local governments rarely use their power to change tax rates, although they are allowed to adjust 11 of them by as much as $50 \%$ above or below the standard rate. This reflects the reluctance of local governments to diverge from norms set by the national authorities. It is believed that lowering tax rates would lead to reductions in grants, although there is no direct link between them, according to the central government (OECD Economic Surveys: Korea, 2005). When local authorities want to raise expenditures, they tend to ask for increases in intergovernmental grants because it is politically easier than raising taxes. 


\section{The Korean tax system in an international perspective}

9. The central government tax system consists of; $i$ ) ten "internal taxes"; ${ }^{7}$ ii) three earmarked taxes (education, local development and transport-energy-environment); ${ }^{8}$ and iii) customs duties. The central government transfers $19.2 \%$ of internal tax revenues to local governments as general grants known as the "Local Share Tax", based on a formula aimed at reducing inequality in regional income. Another $19.4 \%$ is transferred to the education special account.

10. In terms of the tax mix, Korea is unique in a number of respects (Table 2):

- Direct taxes on households are exceptionally low, accounting for only $15.2 \%$ of total tax revenue in 2006, the fifth-lowest share in the OECD area. Only one-half of wage earners pay personal income tax (PIT) due to a number of deductions and, consequently, only one-half of wage income is subject to tax. PIT revenue is further reduced by preferential tax treatment of income from a number of sources, including retirement benefits and agriculture. ${ }^{9}$ Capital gains from financial assets are largely untaxed.

- Corporate income tax (CIT) revenue accounted for $14.3 \%$ of tax revenue in 2006, well above the OECD average of $10.7 \%$. The standard rate of $27.5 \%$ and the amount of revenue, at $3.8 \%$ of GDP, are in line with OECD averages.

- Social security contributions have become the largest single source of government revenue. However, the share of contributions in GDP, at $5.7 \%$, is well below the OECD average due to relatively low contribution rates and weak compliance with the public pension system.

- Taxes on goods and services account for about one-third of government revenue, as in the OECD area. The VAT accounts for half of this amount, although the rate, at $10 \%$, is the fourth lowest in the OECD. The other half is derived from a wide range of excises on specific products. Customs and import duties provide $3.1 \%$ of tax revenue, one of the highest shares in the OECD area.

- The property tax accounted for $13.2 \%$ of tax revenue in 2006, well above the OECD average of $5.7 \%$. This is due to transaction taxes on property, such as the registration and acquisition taxes. Taxes assessed on property itself (recurrent taxes) are much lower than the OECD average. Estate, inheritance and gift taxes in Korea accounted for $1.1 \%$ of tax revenue, the third highest in the OECD area.

- Another unusual aspect of Korea's tax system is the important role of so-called quasi-taxes, which include a wide range of fees, charges and contributions that are not imposed by the tax laws. Most are levied on firms in a discretionary and non-transparent manner for financing off-

7. The ten internal taxes include the income tax, corporation tax, inheritance tax, gift tax, Comprehensive Property Tax, VAT, individual consumption tax, liquor tax, stamp tax and securities transaction tax.

8. These earmarked taxes accounted for $12 \%$ of central government tax revenue in 2007 . The education tax, a surtax on four other taxes, provides revenue for the education special account. The special tax for local development, a surcharge on a number of national and local taxes, funds programmes to enhance the competitiveness of agriculture and fishing. The transportation-energy-environment tax, an excise on gasoline and diesel, is earmarked to transport infrastructure (80\%), the environment (15\%), energy $(3 \%)$ and regional development $(2 \%)$.

9. Agriculture income is taxed only at the local government level and at very low effective rates. In the FY 2007 budget, such revenue was expected to be zero. 
budget spending. There were some 100 such quasi-taxes in 2006, generating income of $1.4 \%$ of GDP.

Table 2. The tax mix in OECD countries

\section{A. Tax revenue as a per cent of GDP}

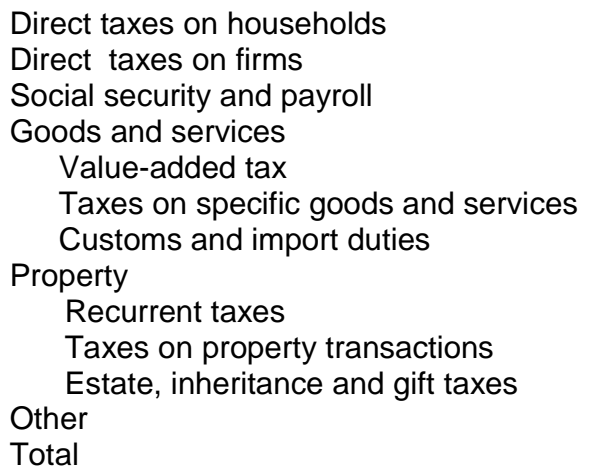

\begin{tabular}{rr|rrr|rr}
\multicolumn{2}{c|}{2000} & \multicolumn{3}{c|}{2006} & \multicolumn{2}{c}{$\begin{array}{c}\text { Change 2000 to } \\
2006\end{array}$} \\
\hline Korea & OECD & Korea & Rank & OECD & Korea & OECD \\
\hline 3.4 & 9.7 & 4.1 & 27 & 9.2 & 0.7 & -0.5 \\
3.3 & 3.6 & 3.8 & 10 & 3.9 & 0.5 & 0.3 \\
3.9 & 9.3 & 5.7 & 22 & 9.4 & 1.8 & 0.1 \\
9.0 & 11.2 & 8.7 & 26 & 11.1 & -0.3 & -0.1 \\
4.0 & 6.6 & 4.5 & 24 & 6.8 & 0.5 & 0.2 \\
4.0 & 4.4 & 3.4 & 22 & 4.1 & -0.6 & -0.3 \\
1.0 & 0.2 & 0.8 & 2 & 0.2 & -0.2 & 0.0 \\
2.9 & 1.9 & 3.5 & 3 & 2.0 & 0.6 & 0.1 \\
0.6 & 0.9 & 0.8 & 12 & 1.0 & 0.2 & 0.1 \\
2.0 & 0.7 & 2.4 & 1 & 0.7 & 0.4 & 0.0 \\
0.3 & 0.3 & 0.3 & 7 & 0.2 & 0.1 & -0.1 \\
0.9 & 0.3 & 0.9 & 4 & 0.3 & 0.0 & 0.0 \\
23.4 & 36.0 & 26.7 & 26 & 35.9 & 3.3 & -0.1
\end{tabular}

\begin{tabular}{|c|c|c|c|c|c|c|c|}
\hline \multicolumn{8}{|c|}{ B. Tax revenue as a per cent of total tax revenue } \\
\hline & \multicolumn{2}{|c|}{2000} & \multicolumn{3}{|c|}{2006} & \multicolumn{2}{|c|}{$\begin{array}{c}\text { Change } 2000 \text { to } \\
2006\end{array}$} \\
\hline & Korea & OECD & Korea & Rank & OECD & Korea & OECD \\
\hline Direct taxes on households & 14.6 & 26.1 & 15.2 & 26 & 24.8 & 0.6 & -1.3 \\
\hline Direct taxes on firms & 14.1 & 10.1 & 14.3 & 5 & 10.7 & 0.2 & 0.6 \\
\hline Social security and payroll & 16.9 & 25.5 & 21.2 & 21 & 26.2 & 4.3 & 0.7 \\
\hline Goods and services & 38.3 & 31.6 & 32.6 & 12 & 31.5 & -5.6 & 0.0 \\
\hline Value-added tax & 17.0 & 18.5 & 16.8 & 21 & 19.3 & -0.2 & 0.7 \\
\hline Taxes on specific goods and services & 16.9 & 12.4 & 12.7 & 8 & 11.6 & -4.2 & -0.7 \\
\hline Customs and import duties & 4.3 & 0.6 & 3.1 & 3 & 0.6 & -1.2 & 0.0 \\
\hline Property & 12.4 & 5.5 & 13.2 & 1 & 5.7 & 0.8 & 0.2 \\
\hline Recurrent taxes & 2.5 & 2.6 & 3.1 & 9 & 3.0 & 0.6 & 0.3 \\
\hline Taxes on property transactions & 8.5 & 2.0 & 9.1 & 1 & 2.1 & 0.6 & 0.1 \\
\hline Estate, inheritance and gift taxes & 1.4 & 0.9 & 1.1 & 3 & 0.6 & -0.3 & -0.2 \\
\hline Other & 3.7 & 1.2 & 3.5 & 3 & 1.1 & -0.2 & -0.1 \\
\hline Total & 100.0 & 100.0 & 100.0 & & 100.0 & 0.0 & 0.0 \\
\hline
\end{tabular}

Source: OECD (2008c), Revenue Statistics 1965-2007, OECD, Paris (http://dx.doi.org/10.1787/366725334503).

11. Local government taxes account for about one-fifth of total tax receipts and cover about one-third of local government spending. There are basically two levels of local government in Korea. The upper-level local government consists of nine provinces, six metropolitan cities and Seoul special city, while lower-level local government includes cities, counties and wards (OECD Economic Surveys: Korea, 2005). Authority for education is located in the "local education governments", which are independent of local general government and rely primarily on the central government for revenue. The 16 local taxes generated an estimated $4.2 \%$ of GDP in 2007. Nine key taxes accounted for 93\% of local tax revenue in 2007. The remaining taxes, each generating less than $2 \%$ of local tax revenue, reflects the reliance on earmarked taxes, which in total account for $21 \%$ of local government tax revenue. ${ }^{10}$ One of the five

10. Excluding the local education tax, which in practice is controlled by the central government, would reduce the share of earmarked taxes to $9 \%$ (and raise the share for the central government to $15 \%$ ). 
earmarked taxes, the Local Education Tax, is a major revenue source. It was introduced in 2001 as a surcharge on five local taxes, but is transferred directly to local education governments and thus does not enhance the autonomy of local general governments (Kim, 2005). Property taxes account for about half of local tax revenue (Figure 4), with levies on transactions accounting for about four-fifths of that amount. However, local property taxes were reduced with the introduction of a national Comprehensive Property Tax (CPT) in 2005. In contrast, local taxes on consumption, business and personal income, as well as local social security and payroll taxes, are relatively insignificant compared to other OECD countries.

Figure 4. Composition of sub-national government tax revenues

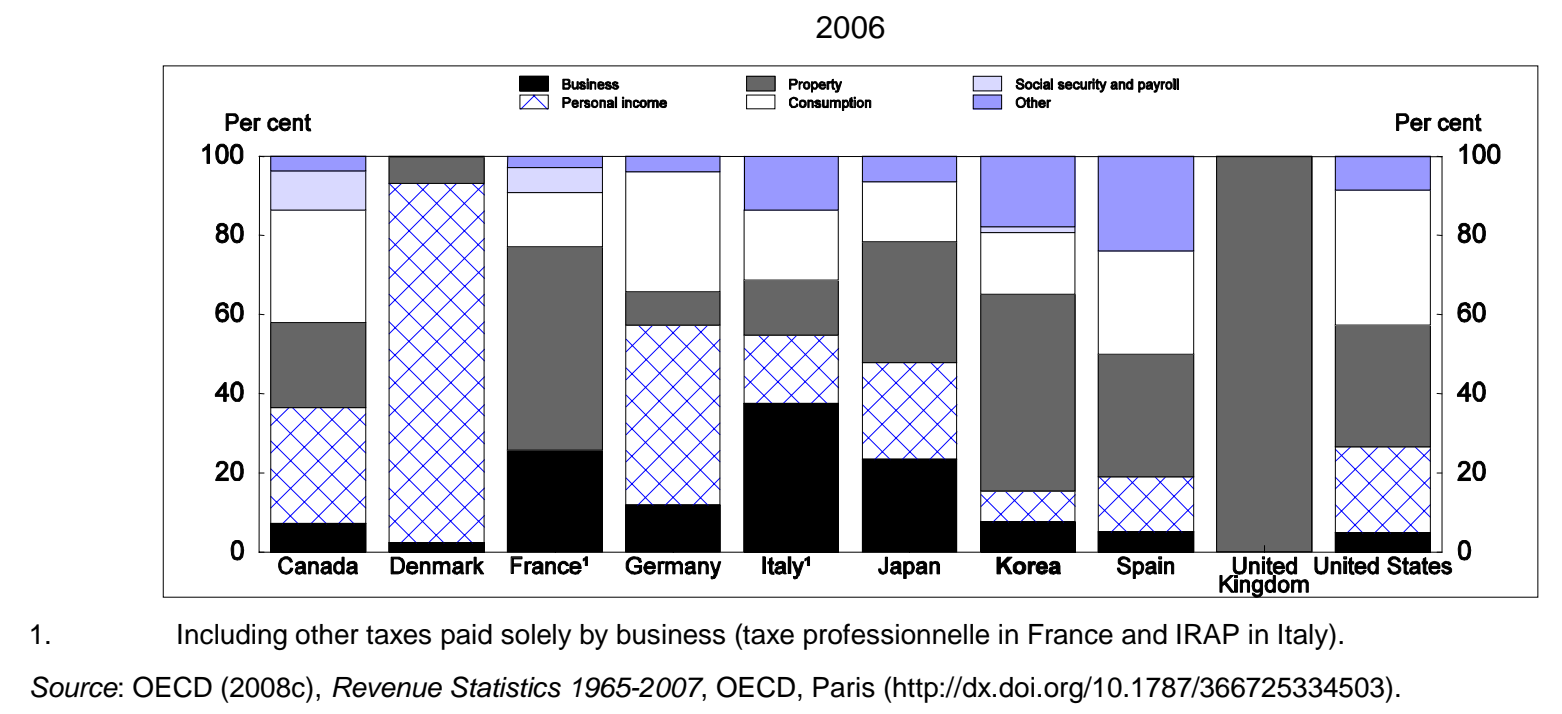

12. Korea has made some progress in implementing the tax reform recommendations in the 2000 OECD Economic Surveys: Korea (Annex 1). In September 2008, the government announced a tax reform package aimed at boosting private consumption and business and housing investment:

- $\quad$ PIT rates will be cut by two percentage points by 2010 , lowering the range from $8 \%$ to $35 \%$ to $6 \%$ to $33 \%$. Inheritance tax rates, currently $10 \%$ to $50 \%$, will be brought in line with the PIT. In addition, the personal income tax deduction will be hiked from 1 million won to 1.5 million won.

- The CIT rate (central government) will be cut from $25 \%$ to $22 \%$ in 2009 and $20 \%$ in 2010 . The rate for small and medium-sized enterprises (SMEs) was reduced from $13 \%$ to $11 \%$ in 2008 and will be lowered further to $10 \%$ in 2010 and the threshold for this lower rate will be doubled to 200 million won. As a result, $90 \%$ of firms will pay the SME rate.

- The threshold for paying capital gains tax for those owning only one house will be raised from 600 million won (\$409 000) to 900 million won (\$613 000). The special deduction for long-term ownership will be expanded from $4 \%$ to $8 \%$ per year (up to a maximum of $80 \%$ ). The tax rates on capital gains, which are one percentage point higher than the PIT for each bracket, and the thresholds will be brought into alignment with the PIT in 2009.

- The CPT will be significantly revised. First, the rates will be cut from a range of $1 \%$ to $3 \%$ to $0.5 \%$ to $1 \%$. Second, the threshold for paying the tax will be raised from 600 million won to 900 million won. Third, the "application ratio" used to calculate the tax base will be kept constant rather than increased as originally planned. Fourth, tax rates on land will also be reduced. 
While there are a number of positive elements in this plan, it does not fully address the four challenges noted above, which require a more comprehensive tax reform. The following sections examine the CIT, PIT, consumption taxes (including environmentally-related taxes) and property taxes.

\section{Corporate taxation}

\section{Overview of the corporate income tax}

13. Corporate tax receipts have increased in recent years, rising from 3.3\% of GDP in 2000 to match the OECD average of $3.8 \%$ by 2006 (Table 2). One factor is the $66 \%$ rise in the number of corporations, as restructuring in the wake of the crisis prompted newly-unemployed persons to create enterprises and firms to spin off unprofitable divisions. ${ }^{11}$ In addition, taxable profits have risen markedly, in part due to deleveraging in the corporate sector since the financial crisis; the debt-equity ratio in the manufacturing sector fell from nearly $400 \%$ in 1997 to less than $100 \%$ by 2005 , thereby reducing deductions for corporate interest payments. In addition, with loss carryovers limited to five years, the large losses recorded in the wake of the crisis can no longer be used to offset profits.

14. The corporate tax system accounted for 84 of the 219 tax expenditures in 2006 and $28.5 \%$ of the total amount of tax expenditures (Table 3). Since 2000, they have remained steady at around one-fifth of corporate tax revenue. This is relatively high compared with other OECD countries, notably Japan, where they amounted to $7 \%$ of corporate tax revenue in 2006. Incentives for investment promotion, R\&D and SMEs accounted for $80 \%$ of the total (Table 4). Tax expenditures for investment promotion include measures to attract foreign direct investment (FDI) inflows by cutting or eliminating taxes on foreign companies for up to seven years. In addition, the rate of tax subsidy for R\&D expenditures in Korea is relatively generous, ranking in the upper half of OECD countries (Figure 5). As for SMEs, in addition to tax expenditures, Korea is one of ten OECD countries that levy a reduced CIT rate on small firms.

Figure 5. Tax treatment of R\&D in Korea is relatively generous

Rate of tax subsidy for one unit of R\&D in $2008^{1}$

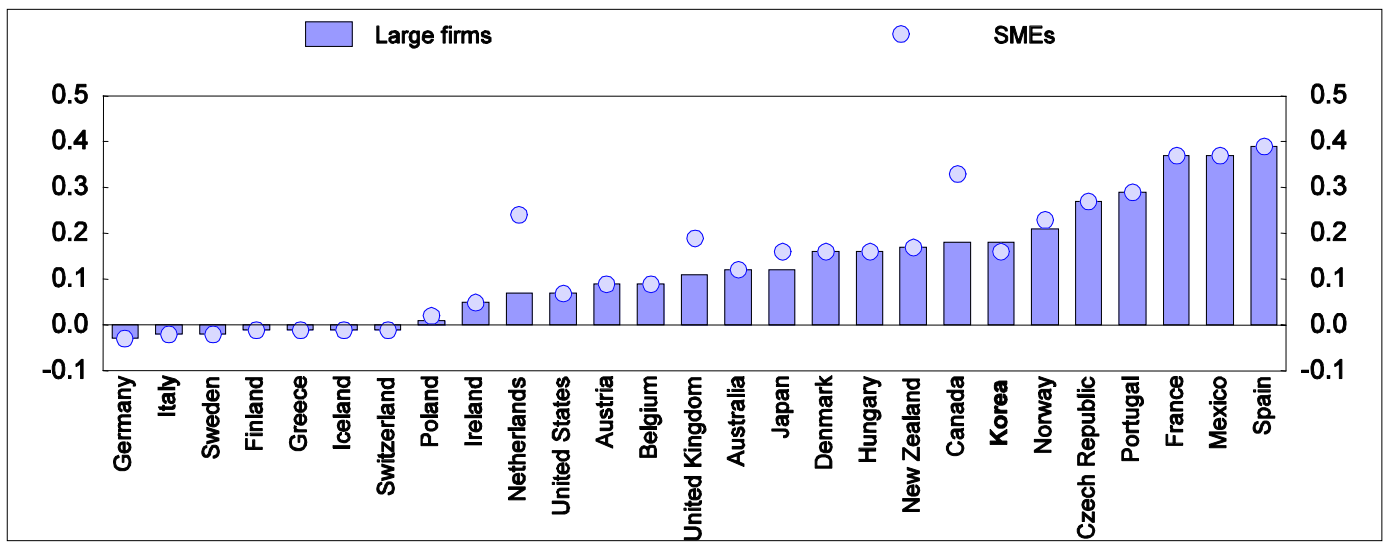

1. For example, the score of 0.18 for large firms in Korea means that 100 won of R\&D spending resulted in 18 won of tax relief for them.

Source: OECD (2008d), Science, Technology and Industry Scoreboard, OECD, Paris.

11. The proportion of firms paying corporate taxes has remained steady at around two-thirds since 2000 . 
Table 3. Tax expenditures in Korea

\begin{tabular}{|c|c|c|c|c|c|}
\hline & 2000 & 2002 & 2004 & 2006 & Number \\
\hline $\begin{array}{l}\text { Personal income tax (trillion won) } \\
\text { Per cent of revenue }\end{array}$ & $\begin{array}{r}5.2 \\
25.9\end{array}$ & $\begin{array}{r}5.6 \\
26.1\end{array}$ & $\begin{array}{r}7.4 \\
28.3\end{array}$ & $\begin{array}{r}9.1 \\
26.2\end{array}$ & 96 \\
\hline Per cent of all tax expenditures & 38.9 & 37.7 & 40.5 & 42.7 & \\
\hline Per cent of GDP & 0.9 & 0.8 & 0.9 & 1.1 & \\
\hline $\begin{array}{l}\text { Corporate income tax (trillion won) } \\
\text { Per cent of revenue }\end{array}$ & $\begin{array}{r}4.3 \\
22.5\end{array}$ & $\begin{array}{r}4.6 \\
21.6\end{array}$ & $\begin{array}{r}5.7 \\
20.8\end{array}$ & $\begin{array}{r}6.1 \\
18.9\end{array}$ & 84 \\
\hline Per cent of all tax expenditures & 32.6 & 31.2 & 31.1 & 28.5 & \\
\hline Per cent of GDP & 0.7 & 0.7 & 0.7 & 0.7 & \\
\hline $\begin{array}{l}\text { Value-added tax (trillion won) } \\
\text { Per cent of revenue }\end{array}$ & $\begin{array}{r}2.6 \\
11.4\end{array}$ & $\begin{array}{l}3.0 \\
9.6\end{array}$ & $\begin{array}{l}3.2 \\
9.2\end{array}$ & $\begin{array}{r}3.8 \\
10.0\end{array}$ & 25 \\
\hline Per cent of all tax expenditures & 19.9 & 20.6 & 17.4 & 17.8 & \\
\hline Per cent of GDP & 0.5 & 0.4 & 0.4 & 0.4 & \\
\hline $\begin{array}{l}\text { Other indirect taxes (trillion won) } \\
\text { Per cent of revenue }\end{array}$ & $\begin{array}{l}0.9 \\
1.6\end{array}$ & $\begin{array}{l}1.3 \\
1.8\end{array}$ & $\begin{array}{l}1.8 \\
2.1\end{array}$ & $\begin{array}{l}2.1 \\
2.2\end{array}$ & 60 \\
\hline Per cent of all tax expenditures & 7.0 & 8.6 & 9.6 & 9.6 & \\
\hline Per cent of GDP & 0.2 & 0.2 & 0.2 & 0.2 & \\
\hline $\begin{array}{l}\text { Property taxes (trillion won) } \\
\text { Per cent of revenue }\end{array}$ & $\begin{array}{l}0.2 \\
1.2\end{array}$ & $\begin{array}{l}0.3 \\
1.3\end{array}$ & $\begin{array}{l}0.3 \\
1.2\end{array}$ & $\begin{array}{l}0.3 \\
1.0\end{array}$ & 3 \\
\hline Per cent of all tax expenditures & 1.6 & 1.9 & 1.4 & 1.4 & \\
\hline Per cent of GDP & 0.0 & 0.0 & 0.0 & 0.0 & \\
\hline $\begin{array}{l}\text { Total tax expenditures (trillion won) } \\
\text { Per cent of revenue }\end{array}$ & $\begin{array}{r}13.3 \\
9.7\end{array}$ & $\begin{array}{r}14.7 \\
8.8\end{array}$ & $\begin{array}{r}18.3 \\
9.5\end{array}$ & $\begin{array}{r}21.3 \\
9.4\end{array}$ & 219 \\
\hline Per cent of GDP & 2.3 & 2.2 & 2.3 & 2.5 & \\
\hline
\end{tabular}

1. The number of individual tax expenditures in 2006. The total number is less than the components as some tax expenditures apply to more than one tax.

Source: Ministry of Strategy and Finance.

Table 4. Tax expenditures in the corporate tax system

Per cent of corporate tax revenue

\begin{tabular}{|c|c|c|c|c|}
\hline & 2000 & 2002 & 2004 & 2006 \\
\hline Investment promotion & 4.8 & 4.3 & 8.1 & 8.0 \\
\hline R\&D promotion & 5.0 & 4.4 & 4.5 & 4.0 \\
\hline Promotion of SMEs & 2.0 & 3.3 & 3.6 & 3.0 \\
\hline Social security payments & 4.1 & 4.2 & 1.7 & 1.7 \\
\hline Promotion of agriculture and fishing & 0.3 & 0.4 & 0.1 & 1.0 \\
\hline Rural development & 0.7 & 1.3 & 1.2 & 0.4 \\
\hline Restructuring of financial industry & 3.5 & 1.7 & 1.1 & 0.3 \\
\hline Education and culture & 0.8 & 1.0 & 0.3 & 0.2 \\
\hline Other & 1.3 & 1.0 & 0.3 & 0.1 \\
\hline Total tax expenditures & 22.5 & 21.6 & 20.8 & 18.9 \\
\hline
\end{tabular}

Source: Ministry of Strategy and Finance. 


\section{Promoting economic growth}

15. Statutory corporate tax rates have fallen in the OECD area (Figure 6), reflecting a growing recognition that taxes on corporate income distort saving and investment decisions, reducing economic growth. In addition, there has been active competition to lower rates to attract FDI in a world of increasingly mobile capital. Evidence suggests that differences in corporate tax rates affect international flows of capital and profits and the location decisions of firms. For example, an OECD study found that a one percentage-point increase in the effective corporate tax rate reduces the stock of FDI by between $1 \%$ and 2\% (Hajkova et al., 2006). Another study reported that a one percentage-point cut in the rate can raise the stock of FDI by about 3.3\% (de Mooij and Ederveen, 2003). In addition, globalisation has increased opportunities for tax avoidance. International differences in corporate tax rates create incentives for more aggressive use of transfer pricing by multinationals, which shift profits to subsidiaries in countries that have lower tax rates and costs to countries with higher tax rates. ${ }^{12}$

16. The statutory corporate tax rate in Korea fell from $30.8 \%$ (including the local government $\operatorname{tax}^{13}$ ) in 2000 to $27.5 \%$ in 2005, a rate close to the OECD average, which itself has declined over time (Figure 6). As noted above, the rate is to be cut from $27.5 \%$ to $22 \%$ by 2010 , which would be the third lowest in the OECD. The government's concern is to compete with other Asian countries. For example, the rate is $25 \%$ in both China and Taiwan, China, $18 \%$ in Singapore and $16.5 \%$ in Hong Kong, China.

17. A further cut in the corporate tax rate may help end the downward trend in business investment from $26 \%$ of GDP in 1996 before the crisis to $19 \%$ in 2006. The business sector argues that, in addition to lower tax rates, their tax burden should be lightened by expanding deductions and credits, depreciation allowances and loss carryovers. However, such an approach would risk complicating the tax code, thereby raising both compliance costs and incentives for tax evasion. Therefore, the reduction in the corporate tax burden should be achieved by cutting the tax rate rather than narrowing the base.

18. In addition to lowering tax rates, the tax burden on corporations should be cut by phasing out quasi-taxes. The 2001 law on quasi-taxes required that both the authority responsible for the collection of quasi-taxes and the purpose of the revenue be clearly identified and placed restrictions on the creation of new quasi-taxes. While this reform helped keep the number of quasi-taxes constant at around 100, their total amount rose from $1.1 \%$ of GDP in 2001 to $1.4 \%$ in $2006 .{ }^{14}$ Given that quasi-taxes reduce transparency and predictability, they should be phased out.

12. Such transfers are facilitated by the increasing proportion of intangible assets, such as patents, in corporate assets. Indeed, intangible assets account for $75 \%$ of the total net assets of Fortune 500 companies, making it easier to relocate activities and tax bases around the world.

13. The local government tax is set at $10 \%$ of the central government rate. Thus, the overall rate of $30.8 \%$ in 2000 was the sum of the $28 \%$ central government rate and a $2.8 \%$ local government rate. At present, the rates are $25 \%$ and $2.5 \%$, respectively.

14. Other estimates of quasi-taxes are higher. An economist at the Korea Economic Research Institute (affiliated with the Federation of Korea Industries) estimated quasi-taxes at 2.6\% of GDP in 2005 (Kim, 2007). An economist at the Korea Institute of Public Finance (affiliated with the government) estimated them at between $2.3 \%$ and $3.2 \%$ of GDP in 2003, well above the government estimate of $1.4 \%$. 
Figure 6. International comparison of statutory corporate income tax rates

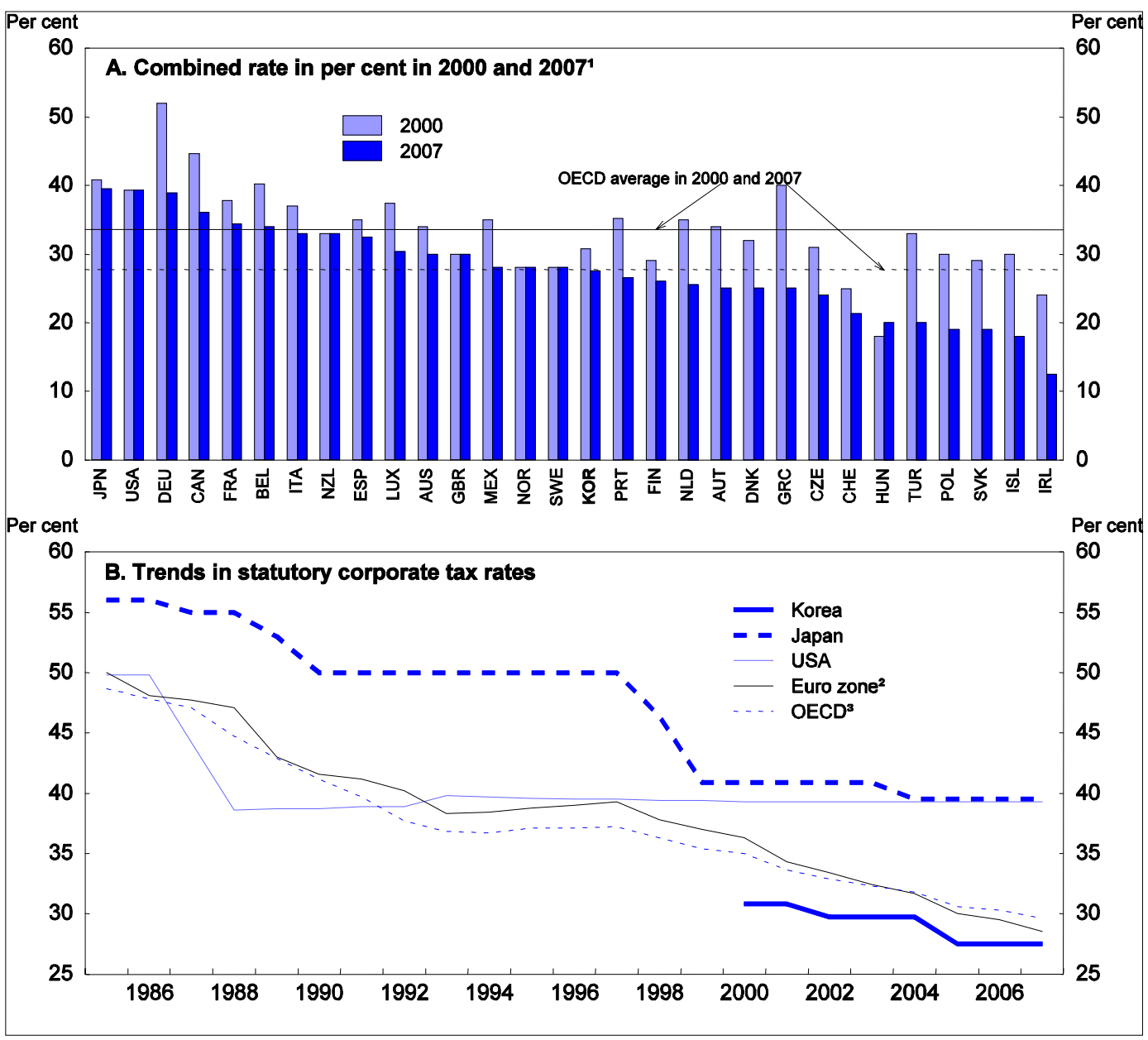

1. Basic combined central and sub-central (statutory) CIT rate. Averages are unweighted.

2. Unweighted mean, excluding Luxembourg.

3. Unweighted mean of 22 OECD countries. It thus differs from the OECD averages shown in Panel A, which include all 30 OECD countries.

Source: OECD (2008e), Tax Database, OECD, Paris (www.oecd.org/ctp/taxdatabase).

\section{Ensuring adequate revenue}

19. The CIT should not be considered as a source of additional revenue to meet the spending demands related to population ageing, given that cuts in the tax rate to boost growth may reduce revenue. The government expects the cut in the CIT rate to reduce revenues. Indeed, following the 2005 cut from $29.7 \%$ to $27.5 \%$, corporate tax revenue fell by 0.3 percentage point of GDP in $2006 .{ }^{15}$ The longerterm impact of the planned CIT cut on total revenue is not clear-cut, however. Its impact is likely to be partially mitigated by positive supply-side effects, as the lower rates crowd in previously unprofitable projects. Indeed, the amount of taxable corporate income tends to be higher in countries with low CIT rates (Figure 7) and, consequently, there is almost no correlation between the statutory CIT tax rate and

15. According to one international study, the revenue-maximising corporate tax rate is around $28 \%$ (Mintz, 2007). 
corporate tax receipts as a share of GDP (Panel B). In any case, tax rate cuts should be accompanied by base broadening to limit any revenue loss. Base broadening would also reduce distortions and improve the allocation of capital. Achieving the positive impact of tax cuts on growth depends in part on the efficient allocation of the higher level of investment.

20. With tax expenditures amounting to one-fifth of corporate tax revenue (Table 4), reducing their number and scope would add significantly to the revenue base. The amount of foregone revenue from measures to promote FDI has doubled from 200 billion won in 2002 to 400 billion won in 2006. However, FDI inflows have been on a declining trend since 2004 (on a notification basis), suggesting that tax incentives are not the most important factor in attracting foreign firms. Tax expenditures to promote $R \& D$ have been justified on the grounds that without them, investment in R\&D would fall short of the socially optimal level, due to spillover effects. However, some countries such as Finland and Sweden, which are front-runners in innovation, do not provide any tax relief for R\&D. While tax incentives tend to provide a stronger stimulus for R\&D than direct subsidies, their overall impact on innovation appears to be small (Jaumotte and Pain, 2005). Korea should ensure that the benefits of additional R\&D spending resulting from tax expenditures outweigh their costs. As for SMEs, they face a CIT rate of only 11\%. However, it is uncertain whether the lower tax rate is the best way of addressing the problems facing SMEs. Small firms are less influenced by the corporate tax rate as they tend to have low profitability (Johansson et al., 2008). Moreover, a low tax rate encourages small firms to remain small in order to benefit from the lower tax rate. Compared to preferential rates for SMEs, a lower general corporate tax rate would have a larger impact on productivity. In sum, the special tax rate for SMEs should be phased out.

21. It is also important to effectively implement recent reforms to control tax expenditures. In particular, strictly applying the sunset clause in the 1998 Special Tax Treatment Law and implementing the 2007 National Fiscal Act would help limit tax expenditures. First, a "PAYGO" principle is applied to requests for additional tax expenditures. This requires that the expected revenue effect of any new tax expenditure be offset by the reduction or elimination of existing tax expenditures. Second, the amount of tax expenditures, as a share of total revenue plus tax expenditures, is not allowed to rise by more than $0.5 \%$ from its average over the preceding three years. Third, a tax expenditure budget, containing expenditures for the preceding year and estimates for the current and following year, is to be adopted in 2010. Fourth, the "Tax Expenditure Evaluation Committee", established in 2007, should focus on quantitative assessments of the effectiveness of tax expenditures. In sum, broadening the tax base by reducing tax expenditures would limit the revenue losses from cutting tax rates and make the tax system more efficient and less complicated, thereby promoting growth.

\section{Improving the local tax system}

22. At present, the local CIT is set at $10 \%$ of the rate imposed by the central government, currently $25 \%$. With a rate of $2.5 \%$, the local CIT accounts for only $8 \%$ of local tax revenue. Given its high volatility in revenue and the large gap in tax bases between jurisdictions, the CIT is not an appropriate source of local government revenue. 
Figure 7. International comparison of corporate tax rates and tax bases

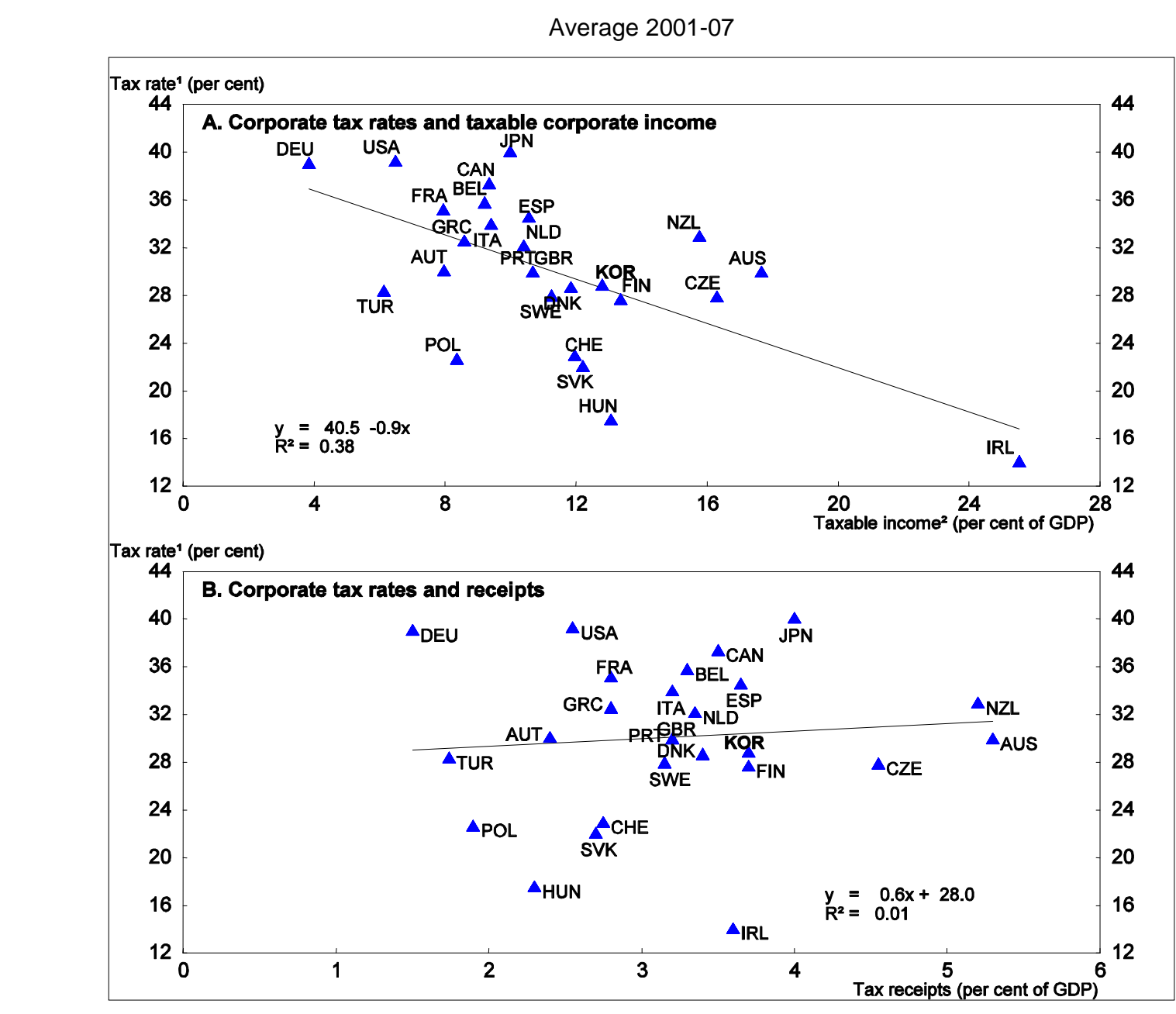

1. Combined central and sub-central statutory CIT rate.

2. Calculated by grossing up corporate tax revenue and dividing by the tax rate.

Source: OECD (2008c), Revenue Statistics 1965-2007, OECD, Paris (http://dx.doi.org/10.1787/366725334503) and OECD (2008e),

Tax Database, OECD, Paris (www.oecd.org/ctp/taxdatabase).

\section{Personal income taxation}

\section{Overview of the personal income tax}

23. The PIT in Korea is exceptionally low, accounting for only $4.1 \%$ of GDP in 2006 (Table 2), the fourth lowest in the OECD area. The top rate was cut from $40 \%$ in 1999 to $35 \%$ in 2005 compared to the OECD average of $43 \%$ (Figure 8). Moreover, as the top rate only applies to incomes exceeding 3.5 times the average wage (Panel B), most taxpayers face much lower rates. In addition, only half of workers pay income tax due to a number of deductions in the PIT system, which accounts for $42.7 \%$ of total tax expenditures in Korea (Table 3). Most important is the deduction on earned income, ${ }^{16}$ which alone

16. All wage income up to 5 million won (23\% of the average wage) is exempted. For wages from:

5 to 15 million won: the deduction is 5 million won plus half of wages exceeding 5 million won.

15 to 30 million won: the deduction is 10 million won plus $15 \%$ of wages exceeding 15 million won.

30 to 45 million won: the deduction is 12.25 million won, plus $10 \%$ of wages exceeding 30 million won.

Beyond 45 million won, the deduction is 13.75 million won plus $5 \%$ of wages exceeding 45 million won. 
accounts for more than half of tax expenditures in the PIT. As a result of the deductions, only half of wage income is subject to tax, the third lowest OECD-wide and well below the average of $84 \%$ (Figure 9).

Figure 8. Top marginal rates and corresponding income threshold

$\ln 2006$

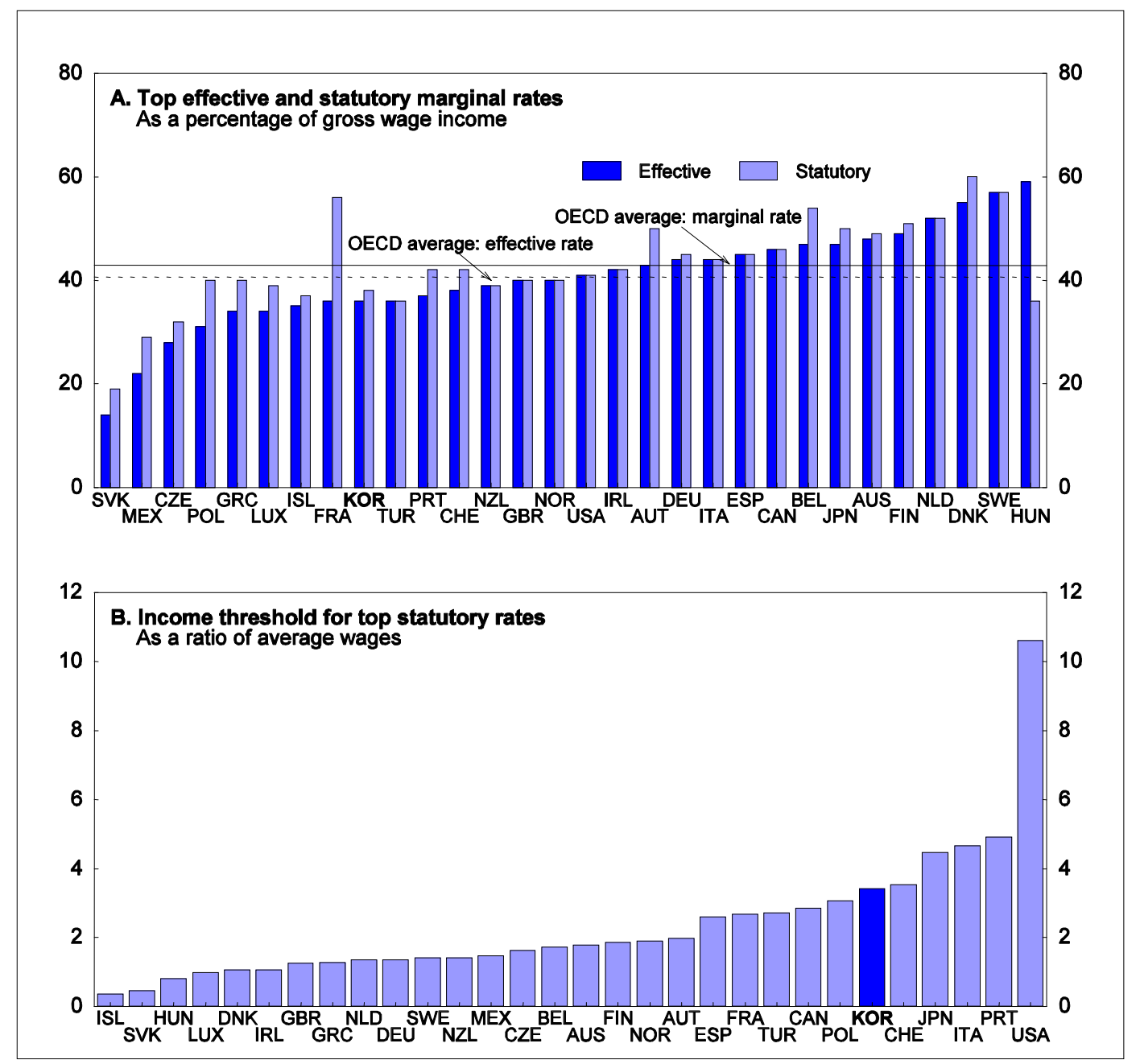

Source: OECD (2008e), Tax Database, OECD, Paris (www.oecd.org/ctp/taxdatabase).

24. Such deductions are intended to create a level playing field between employees and the selfemployed, who face a lighter effective tax burden for several reasons. First, they are able to split household income among family members, thus circumventing the progressivity of the PIT. Second, they can deduct some consumption spending as business expenses, while benefiting from some tax incentives given to corporations. Third, the simplified VAT system for small businesses exempts them from keeping detailed books. Fourth, weaknesses in enforcement make outright evasion a problem. Comparing national income with data from the National Tax Service (NTS) indicates that only about half of self-employed income is reported, compared to more than $80 \%$ for wage income (Table 5). However, considering that non-taxable incomes are included in national income, reported income of the self-employed is estimated at $60 \%$ to $70 \%$ of their total taxable income (Sung and Park, 2008). While taxing the self-employed on an equal basis with wage earners is a concern in most OECD countries, the problem is more severe in Korea given that the proportion of self-employed is the fourth highest in the OECD area. 
Figure 9. International comparison of wage income subject to personal income tax

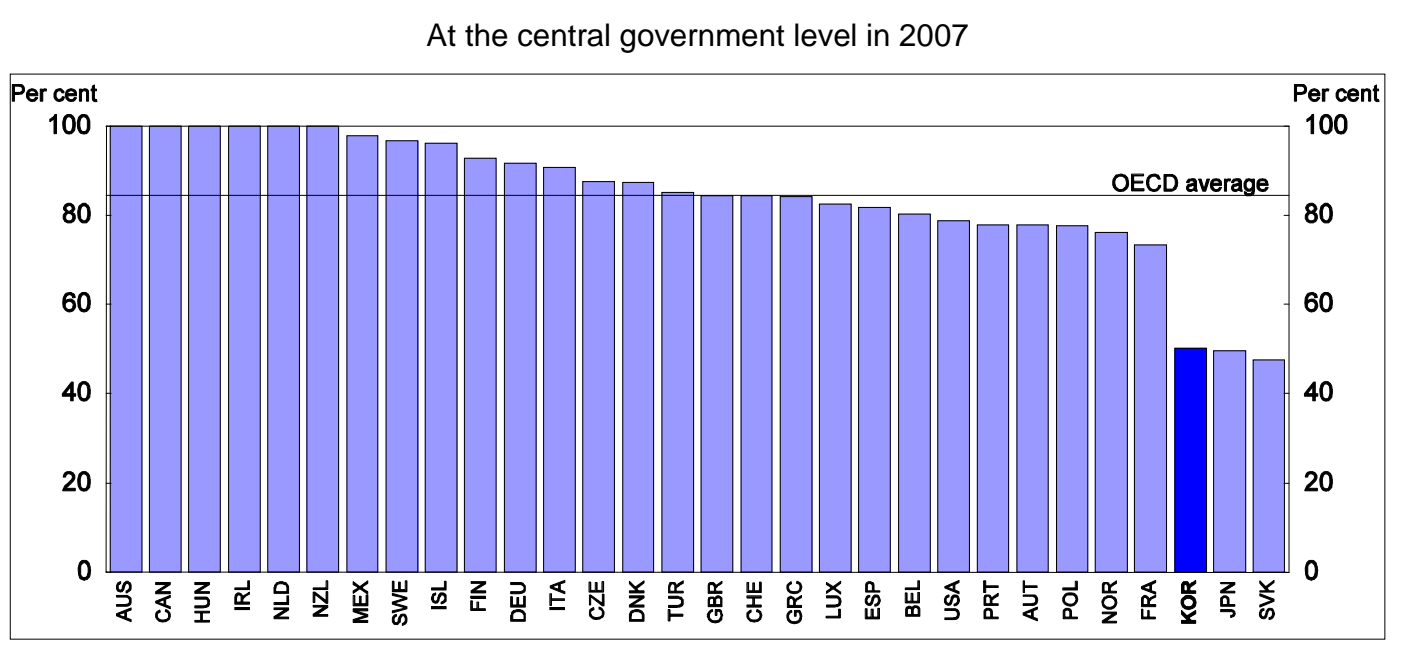

Source: OECD (2007c), Taxing Wages 2006-2007, OECD, Paris.

25. Given the extensive deductions, the PIT burden for a single individual at average earnings in Korea is less than $5 \%$ of gross earnings, the second lowest in the OECD and well below the average of $16 \%$ (Figure 10). The overall tax wedge, including social security contributions, was only $16 \%$ in 2006 , again the second lowest among OECD countries (Panel B). ${ }^{17}$ Another pro-growth aspect of the PIT system is that it does not discourage second-earner participation in the labour force to any significant degree, as the tax unit is the individual rather than the household. In many OECD countries, family taxation tends to discourage the employment of second-earners, typically married women, due to effectively heavier taxation (Jaumotte, 2003). Moreover, the spouse allowance in Korea is relatively low and does not favour non-working spouses. Hence, the low labour force participation rate for women - the fourth lowest in the OECD area (see the 2008 OECD Economic Surveys: Korea) - cannot be blamed on the tax system.

17. The OECD Tax/Benefits model indicates that the average effective tax rate for a transition to full-time work in Korea for persons receiving no unemployment benefits is $10 \%$ to enter work at average earnings. This is the lowest in the OECD area, where the average is $35 \%$. 
ECO/WKP(2009)12

Table 5. Capture ratio of employee and self-employed income

Trillion won

\begin{tabular}{|c|c|c|c|}
\hline & 2005 & 2006 & Increase rates (\%) \\
\hline \multicolumn{4}{|l|}{ National accounts $(\mathrm{A})$} \\
\hline Compensation of employees & 365.0 & 384.8 & 5.4 \\
\hline Self-employed income & 79.7 & 82.5 & 3.5 \\
\hline \multicolumn{4}{|l|}{ Income reported to tax authorities ${ }^{1}(B)$} \\
\hline Employee income & 279.4 & 317.9 & 13.8 \\
\hline Self-employed and rental income & 38.1 & 42.7 & 12.0 \\
\hline \multicolumn{4}{|l|}{ Income capture ratio $(B / A)$ in per cent } \\
\hline Employee income ${ }^{2}$ & 76.5 & 82.6 & 6.1 \\
\hline Self-employed and rental income ${ }^{2}$ & 47.8 & 51.7 & 3.9 \\
\hline \multicolumn{4}{|c|}{ 1. $\quad$ From the National Tax Service's Annual Report on National Taxes. } \\
\hline \multicolumn{4}{|c|}{ 2. The increase shown is in percentage points. } \\
\hline
\end{tabular}

26. In 2008, Korea introduced an earned income tax credit (EITC), an in-work tax credit used in a number of OECD countries, including the United States, the United Kingdom, Denmark, the Netherlands and Sweden. Korea's EITC is initially limited to salaried workers with two or more children, who do not own a home and have assets of less than 100 million won (\$68 000). The income ceiling is 17 million won, $70 \%$ of the average gross household income and $20 \%$ higher than the minimum cost of living for a family of four. The EITC provides 10\% of earnings up to 8 million won and is phased out beginning at 12 million won. The government expects that 0.3 million households (1.8\% of the total) will receive the EITC in 2009 , with total payments of 150 billion won (less than $0.1 \%$ of government spending). The main targets are daily workers ${ }^{18}$ (2.2 million, $9 \%$ of the labour force) and temporary workers (5.2 million, $\left.21 \%\right)$.

18. Daily workers are those with contracts of less than one month. About $70 \%$ are construction workers. 
Figure 10. Korea has a relatively low tax wedge on labour

For a single person with no children

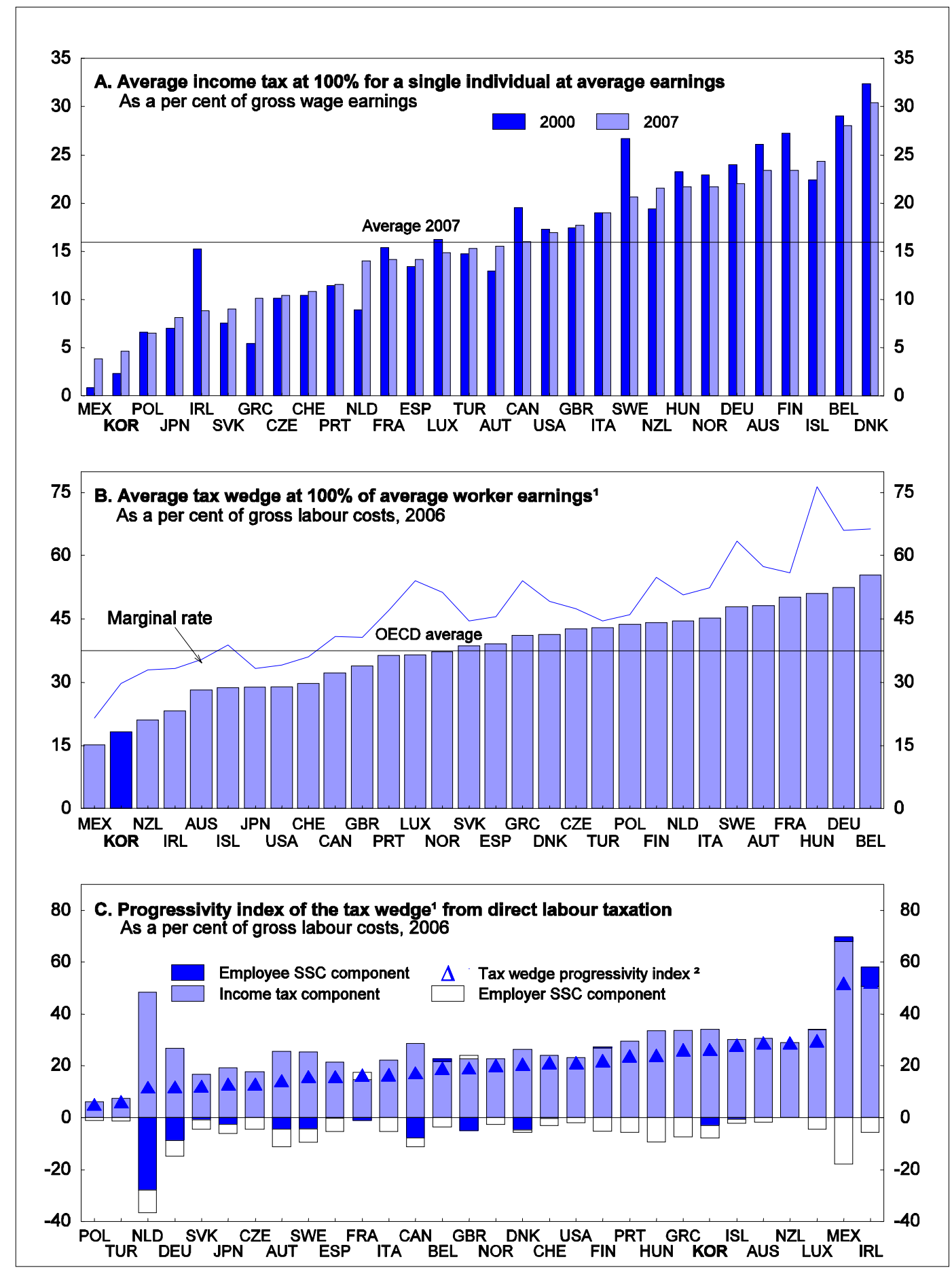

1. The average tax wedge is defined as the share of income tax and all social security contributions minus benefits in gross labour costs. Marginal rates are defined as the increase in income tax and all social security contributions minus benefits as a share of the related increase in gross labour costs.

2. The progressivity index of the tax wedge is calculated as (TW167 - TW67)/ TW167, where TW167 and TW67 are the tax wedges for workers at $167 \%$ and $67 \%$ of the average wage, respectively.

Source: OECD (2008e), Tax Database, OECD, Paris (www.oecd.org/ctp/taxdatabase). 


\section{Promoting economic growth}

27. Cross-country research by the OECD suggests that taxes on labour, such as the PIT and social security contributions, ${ }^{19}$ tend to reduce labour supply and demand, saving and capital investment, thereby reducing potential output growth. According to one study, a 10 percentage-point reduction in the tax wedge on labour (including social security contributions) would boost the employment rate by 3.7 percentage points (OECD, 2006a) ${ }^{20}$ Another OECD study found that a one percentage-point increase in the tax wedge on labour income would lower overall employment by $0.25 \%$ (Bassanini and Duval, 2006). Taxes on labour can also reduce hours worked, especially for women (Causa, 2008). Korea's low marginal tax rate thus boosts working hours and may help explain the low incidence of part-time work by women at $12.5 \%$, about half of the OECD average. Korea should try to maintain a low tax wedge on labour income, thereby helping to sustain labour input, which is currently the highest in the OECD area in terms of hours worked relative to the population.

28. The planned reduction in income tax rates, even if PIT revenue were boosted through base broadening, would be positive for economic growth by enhancing entrepreneurship and incentives for FDI and education. ${ }^{21}$ An OECD study shows that a five percentage-point decrease in the marginal tax rate leads to a 0.3 percentage-point rise in the graduation rate from tertiary education, thereby boosting economic growth (Oliveira Martins et al., 2007). Another study found that the impact of labour taxes on FDI inflows is substantially larger than that of corporate tax rates (Hajkova et al., 2006). As for entrepreneurship, reductions in top PIT rates have been found to raise productivity in industries with high rates of enterprise creation (Johansson et al., 2008). Finally, a further cut in the top personal rate from the planned 33\% in 2010 may help ensure the integrity of the tax system once the national corporate rate falls to $20 \%$, because the wider gap between the two rates may encourage high-income individuals to shelter their income within corporations.

29. Like many OECD countries, Korea has adopted dual taxation of labour and capital income, with a low uniform rate of $14 \%$ on dividend and interest income, an approach that has a number of advantages: i) it reduces any disincentives to save; $i i)$ it helps offset the fact that capital income taxes are applied to the nominal rather than the real return on savings; iii) it reduces the incentive for capital owners to move their savings offshore; and $i v$ ) it reduces the scope for arbitrage between different sources of capital income. However, since 2001, interest and dividend income in excess of 40 million won (\$27 000) is subject to "global taxation", i.e. it is taxed at the same rate as labour income. The number of affected taxpayers rose from 14000 in 2001 to 36000 in 2006 and their tax payments from $0.5 \%$ of GDP to $0.8 \%$. The rationale for this threshold is uncertain and leaving it at this level would mean that a growing share of the population will be subject to global taxation.

30. Changing the favourable tax treatment of the "retirement allowance", which is taxed over a number of years at low rates, would encourage the employment of older workers. Firms are required by law to pay a lump sum of at least one month of wages for each year worked to departing employees. In

19. It has been argued that social security contributions have a smaller impact on labour supply than taxes because they are linked to the social benefits that workers receive later. In Korea, there is only a loose relationship between the contributions paid and the amount of benefits that will be received. First, the pension benefit depends equally on the average wage in the economy and the individual's wage. Second, frequent changes in the pension system have weakened the link between contributions and benefits.

20. The tax wedge measures the difference between total labour compensation paid by the employer and the net take-home pay of employees, as a per cent of total labour compensation.

21. Base broadening, primarily through reducing the deduction for wage income, would primarily impact the $50 \%$ of employees who do not pay income tax. 
practice, many firms pay about double that amount. Given that the lump sum is based on an employee's final wage, which rises sharply with seniority, there is a disincentive to keeping older workers. Most firms therefore set a mandatory retirement age that is well below the age of 60 recommended by the government. Indeed, average tenure peaks around 50, much earlier than in other OECD countries. Making more effective use of older workers is important in an ageing economy (see the 2008 OECD Economic Surveys: Korea). The retirement allowance, which is actually a separation allowance paid each time a worker changes jobs, also discourages labour mobility, given that it is based on seniority and wages. The reduction in mobility has negative consequences for productivity. In 2005, the government introduced a company pension system, which allows firms to transform the lump-sum retirement allowance into a pension, based on agreement between labour and management. However, by September 2008, less than 9\% of firms had adopted a pension system. The government should remove the tax preferences for retirement allowances to promote the employment of older workers, labour mobility and the shift to company pensions.

\section{Ensuring adequate revenue}

31. Boosting PIT revenue from its current low level to offset declines in the CIT resulting from rate cuts would be positive for growth. The key is to further improve tax compliance among the self-employed. The upward trend in the share of PIT revenue in GDP reflects the rise in the proportion of self-employed paying income tax from less than $40 \%$ in 1998 to $63 \%$ in 2006 (Figure 11), as a result of measures to increase transparency about their income. First, the scope for special treatment of small businesses under the VAT was scaled back (see below), increasing their bookkeeping obligations. Second, the government introduced policies in 2000 to encourage the use of credit cards: $20 \%$ of credit card purchases exceeding $20 \%$ of wages are deductible up to a maximum of $20 \%$ of income. In addition, a lottery using credit card receipts was introduced. Between 1999 and 2002, the number of credit cards jumped from 39 million to 104.8 million (three cards per adult), while the amount of purchases increased by more than six times, accounting for $70.3 \%$ of private consumption by 2002 (Table 6). Accordingly, the share of sales captured in the VAT net expanded sharply, increasing transparency about the income of small businesses. ${ }^{22}$

Figure 11. Share of workers paying personal income tax

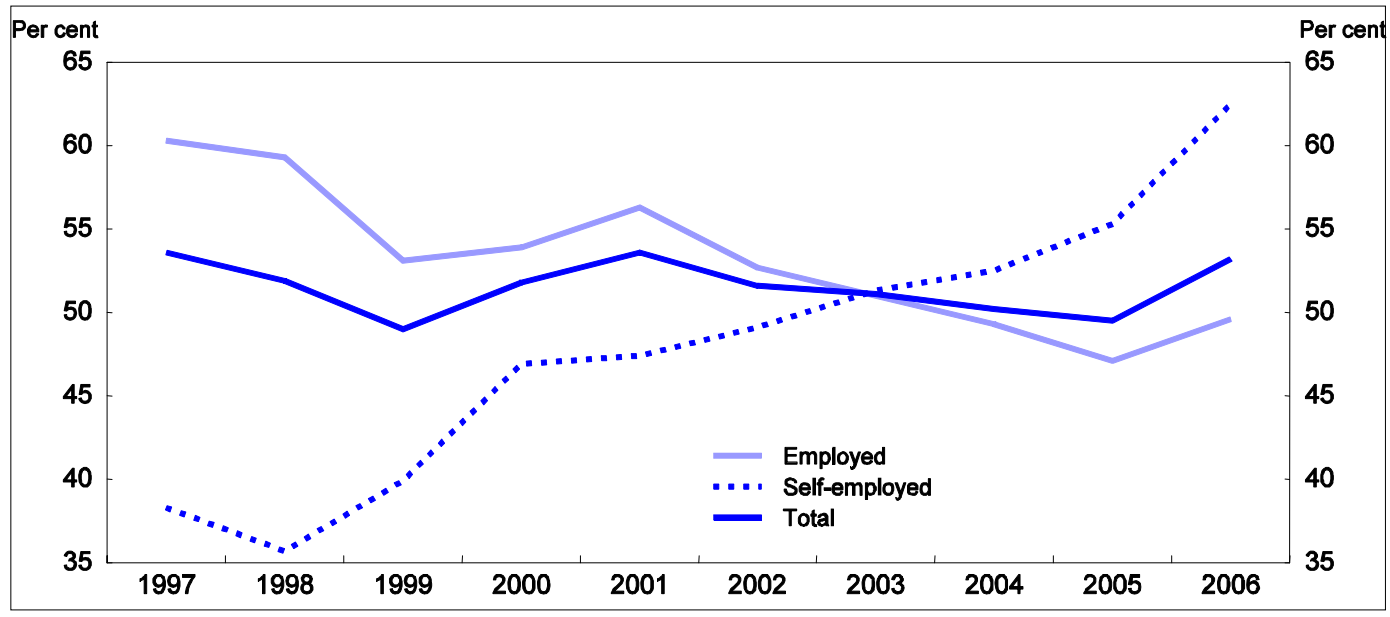

Source: Ministry of Strategy and Finance.

22. However, the expanded use of credit cards led to an epidemic of credit delinquency in the household sector and financial-sector problems (see the 2004 OECD Economic Surveys: Korea). 
32. Policies to further boost the tax compliance of the self-employed remain a priority. Although there is no simple way to accomplish this task, a package of measures may be effective. First, more intensive use of information technology would free up resources to improve enforcement. Second, the number of audits should be increased from its relatively low level and the threshold for investigating suspicious transactions should be lowered. Third, penalties for tax evasion should be strengthened. Fourth, the self-employed should be required to separate their business accounts from their personal accounts.

Table 6. The use of credit cards ${ }^{1}$

In trillion won

\begin{tabular}{lrrrrrrrr}
\hline & 1998 & 1999 & 2000 & 2002 & 2004 & 2005 & 2006 & 2007 \\
\cline { 2 - 8 } Number issued (in millions) & 42.0 & 39.0 & 57.9 & 104.8 & 83.4 & 86.0 & 90.9 & 89.6 \\
Amount of sales using credit cards & 30.8 & 42.5 & 79.9 & 268.0 & 229.9 & 258.2 & 278.9 & 312.0 \\
Per cent of private consumption & 12.9 & 15.5 & 25.6 & 70.3 & 57.3 & 61.2 & 62.7 & 63.6 \\
\hline $1 . \quad$ Includes only non-bank credit card companies. & & & & & &
\end{tabular}

Source: Financial Supervisory Service.

33. In contrast to the self-employed, the share of employees paying PIT declined from $60 \%$ in 1997 to $50 \%$ in 2006, reflecting the large deductions for wage income, keeping the overall proportion of taxpayers at 53\% of workers (Figure 11). Given the increasing tax compliance of the self-employed, there is scope to further boost revenues from the PIT by reversing the fall in the share of employees paying taxes. This requires reducing deductions, notably for wage income, which alone amounts to $15 \%$ of PIT revenue. Such a decline is appropriate given that the amount of deductions for wage income needed to level the playing field with the self-employed is declining. ${ }^{23}$ It should be done by cutting the fixed-amount deduction for each tax bracket so as to not raise marginal tax rates. ${ }^{24}$ Raising the share of wages subject to income tax to the OECD average of $84 \%$ would boost PIT receipts from employees from $1.5 \%$ of GDP to more than $2.5 \%$. Such additional revenue could offset the possible decline in corporate tax revenue in the context of falling CIT rates, as well as the planned cut in the PIT rates. However, using base broadening to finance a cut in the PIT rates would have negative implications for equity.

\section{Coping with income inequality}

34. Korea's PIT system is relatively progressive: the ratio of the tax wedge for a high-income relative to a low-income worker is high (Figure 10, Panel C). However, the narrow income tax base and the small share of PIT receipts in GDP limit its redistributive impact, especially given that tax allowances tend to benefit high-income groups as low-income people are already exempted from income tax. Taxes and social benefits reduce Korea's relative poverty rate by 3 percentage points, compared to an OECD average of 16 points, leaving relative poverty at a high level of $15 \%$ (Figure 3 ). Concerns about inequality and poverty led to the introduction of the EITC, which can "make work pay" for low-skilled persons. It can thus help meet distributional objectives without the negative impact on output growth that may result from raising marginal tax rates on high-income earners.

23. There is some debate about what constitutes a level playing field. While some argue that the self-employed should face a lower tax burden as they face greater risks, a higher tax burden would encourage the shift toward formal employment and would compensate employees for job-related costs.

24. At a minimum, it should be frozen in nominal terms. 
35. In practice, the effect of an EITC on employment depends on the potentially offsetting income and substitution effects and the increase in marginal tax rates as the subsidy fades out. The impact in terms of increasing total labour supply and decreasing unemployment is greater in countries with a wide earnings distribution, low tax rates on labour and low benefits for the non-employed, such as the United States and the United Kingdom (Bassanini et al., 1999). This suggests that the EITC will also be effective in Korea, as it is similar in many respects (Figure 10). Indeed, strict eligibility conditions and the short duration of unemployment benefits reduce the proportion of unemployed receiving benefits to 34\%, compared with an OECD average of $92 \%$. Other government transfers are quite limited in Korea. The main social welfare programme, the National Basic Livelihood Security Programme, is limited to just 3\% of the population. In sum, the EITC is likely to have a positive effect on aggregate employment and poverty in Korea. ${ }^{25}$

36. The EITC is starting on a small scale, with initial coverage of 0.3 million households, a small fraction of the 7.4 million daily and temporary workers targeted by the scheme. An expansion of the EITC could be financed by broadening the PIT base, as discussed above. The major challenge to successfully implementing and expanding the EITC is the lack of transparency about the income of daily and temporary workers, who are generally below the threshold for the income tax. The NTS began to require employers to report the income of such workers only in 2006. Given the lack of transparency and the scope for fraud, the introduction of the EITC on a limited basis is appropriate. The authorities will consider in 2014 whether to extend the eligibility of EITC benefits to the self-employed, where the lack of transparency is even more severe. Given that Korea seems well-suited to an EITC, the objective should be to increase transparency about the income of daily and temporary workers and the self-employed so that the EITC can be available to a larger share of the $15 \%$ of the population living in relative poverty.

37. Another way to improve income distribution would be to increase taxes on fringe benefits. At present, many benefits, such as subsidies for employees buying houses or using lodging or cars owned by their employer, are deductible for firms and not taxable for employees. Fringe benefits are a thus a means to avoid taxes. Given that most non-regular workers do not receive fringe benefits, their tax-free treatment tends to worsen income distribution. Taxing such benefits as individual income, giving priority to those that are most important to high-income earners, would thus increase fairness.

\section{Improving the local tax system}

38. A local income tax on individuals is one option for increasing local government autonomy. At present, the local income tax, which is levied at a rate of $10 \%$ of the PIT and a fixed per capita payment for individuals (the resident tax), accounts for $7 \%$ of local government tax revenue. This share could be increased, either by boosting the per capita levy (collected by the local government), although this would raise inequality, or by hiking the rate on income (collected by the central government). Although local governments are allowed to set the rate between 5\% and 15\%, it remains at $10 \%$ throughout Korea, reflecting their reluctance to diverge from norms set by the central government. Achieving greater revenue autonomy for local governments would require transferring greater spending responsibilities to them, given that many jurisdictions in the capital region are already largely self-sufficient, even though they do not receive the Local Share Tax. Decentralisation would improve the quality of public services in line with local needs. Enhanced local autonomy should be accompanied by increased transfers that are not earmarked to avoid widening regional differences in fiscal capacity.

25. There is a growing body of evidence in OECD countries suggesting that an EITC has a positive effect on aggregate employment (OECD, 2004b). However, there are potential negative effects as well, such as the decline in working hours resulting from the withdrawal of the credit as income rises and the weakened incentives for human capital formation. 


\section{Consumption taxes}

\section{Overview of consumption taxes}

39. The VAT accounted for $16.8 \%$ of total tax revenue in 2006 , while a number of excises on specific goods and services provided another $15.8 \%$ (Table 2). The VAT rate has been fixed at $10 \%$ since its introduction in 1977 and is well below the OECD average of $18 \%$. The relatively low rate is offset by a broad base, as reflected in the VAT Revenue Ratio (VRR) of $72 \%$ in 2005, the fifth highest in the OECD area (Figure 12). The combination of a low rate and a broad base is not unusual as a cross-country comparison indicates a negative correlation between the standard VAT rate and the broadness of the base. ${ }^{26}$ The scaling back of the preferences for small businesses with annual turnover of less than 150 million won ( $\$ 102000$ ) has helped broaden the base. In 1998, nearly $60 \%$ of the 2.9 million businesses paying the VAT were granted "special" or "simplified" treatment, allowing them to pay between $2 \%$ and $4 \%$ of turnover. With the abolition of the special treatment in 2000 and the cut in the ceiling for the simplified scheme to 48 million won, the share of businesses receiving preferential treatment fell to $49 \%$ in 2001 . It declined further to $38 \%$ in $2006,{ }^{27}$ reflecting the increased transparency resulting from greater use of credit cards as well as the unchanged ceiling of 48 million won, which has fallen by a fifth in real terms.

40. Excises on specific goods and services are relatively large in Korea. Although the number of "individual consumption taxes" was reduced from 27 to 20 in 2004, their revenue remains around $0.6 \%$ of GDP. Excises were placed on goods considered to be luxury items ${ }^{28}$ in order to offset the regressive impact of the introduction of the VAT on income distribution. Excises are also imposed on six energy products.

\section{Promoting economic growth}

41. A revenue-neutral reform that raised the share of indirect taxes in total tax revenue is likely to boost the level of per capita income, as noted above. Although consumption taxes lower the real after-tax wage and thereby have a negative effect on labour supply, the extent of the distortion is less than for income taxes. ${ }^{29}$ Korea's broad base for the VAT is appropriate as it reduces the need for a higher rate. Another advantage is that the VAT is simple and relatively difficult to avoid or evade in Korea.

26. The negative correlation may reflect several factors. First, countries with a high standard VAT rate tend to narrow the base by applying a reduced rate to many products, owing to equity concerns. Second, high VAT rates encourage tax evasion.

27. These proportions exclude businesses with less than 24 million won, which are exempted from the VAT.

28. At present, the individual consumption tax covers perfume, jewellery, precious metals, luxury cameras, watches, fur, carpets and furniture, cars of more than $1000 \mathrm{cc}$, slot machines, casinos, racetracks, hunting guns, deer antlers, royal jellies, bars and golf club memberships.

29. Consumption taxes are less efficient than property taxes. However, property taxes are better suited to local authorities. In addition, as they are particularly unpopular, few countries manage to raise substantial revenues from property taxes (Johansson et al., 2008). 
Figure 12. Value-added taxes in OECD countries

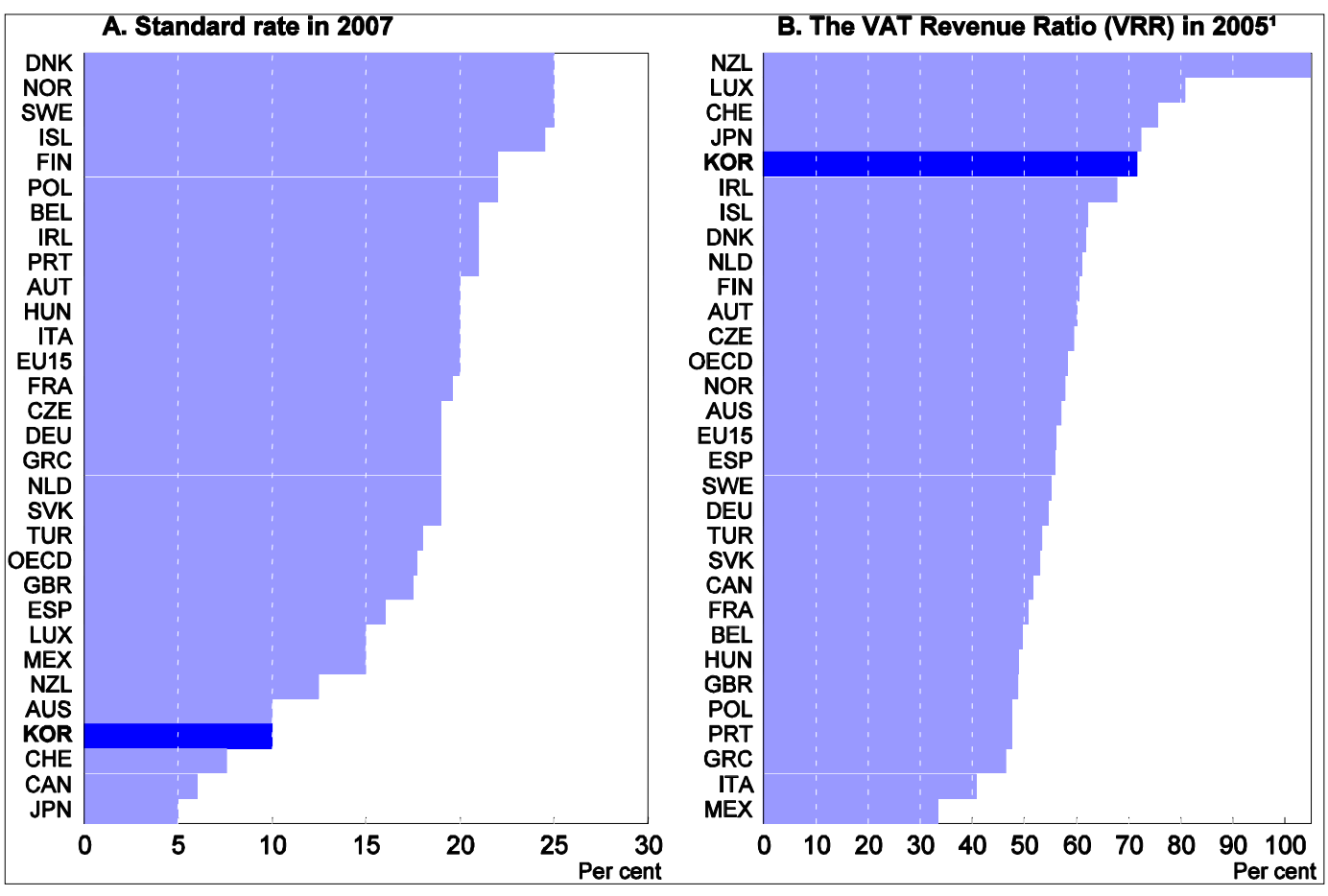

1. VAT Revenue Ratio $=$ (VAT revenue) / [(consumption expenditures - VAT revenue ${ }^{*}$ standard VAT rate]. . The most recent year for which complete data are available is 2005.

Source: OECD (2008a), Consumption Tax Trends, OECD, Paris.

\section{Ensuring adequate revenue}

42. Consumption taxes should be the primary revenue source to finance increased spending in the future. Given the already broad base, generating additional revenue implies hiking the VAT rate from its relatively low level. In addition, there is still room to generate more revenue by broadening the base, ${ }^{30}$ in particular by scaling back the scope of exemptions and limiting the use of the simplified scheme for small businesses. While the scheme alleviates the administrative burden, it distorts competition between firms of different sizes and facilitates tax evasion through a number of channels. First, firms using the special scheme can easily disguise their true turnover as there is no bookkeeping obligation. Second, the absence of bookkeeping also facilitates tax evasion by larger firms that have transactions with businesses using the simplified scheme. The problem extends beyond the VAT as under-reporting of turnover makes it easier for the self-employed to under-report personal income as well. The objective of the simplified scheme should be to reduce administrative burdens on small firms rather than grant them favourable treatment. This requires bringing the value-added ratios used in place of bookkeeping into line with actual valueadded. Using new technology to reduce the compliance cost of the standard VAT would reduce the need for a specialised scheme for small businesses.

30. Broadening the tax base is the best way to generate more VAT revenue as this approach increases efficiency, while raising the rate tends to encourage tax avoidance and the growth of the shadow economy. 


\section{Coping with income inequality}

43. A shift in the tax structure from income to consumption taxes would reduce the tax system's already low redistributive impact, with negative implications for income equality. The need to eventually boost the VAT rate raises the issue of whether to introduce multiple rates in order to limit the regressive impact of the VAT by exempting or imposing lower rates on food and other necessities. Such an approach is used in some European countries, which have standard VAT rates as high as $25 \%$. However, differentiating VAT rates is not an efficient way to provide assistance to those who need it. High-income households tend to benefit most from lower rates on some items because their level of consumption is higher (OECD, 2008a). In addition, introducing multiple VAT rates has a number of drawbacks. First, it would entail higher administrative and compliance costs. Second, it would provide opportunities for fraud through the misclassification of items. Third, it would have to be compensated by a higher standard rate. Fourth, it would reduce the neutrality of the VAT, thus distorting consumption decisions and decreasing welfare. In sum, it is important to maintain a single rate (and limit the number of zero-rate products), while addressing income distribution through better-targeted policy tools, such as the EITC.

44. Consumption taxation should be further improved by simplifying the unnecessarily complex structure of excises. The wide variation in excise rates distorts consumption choices. In particular, the excises on 20 items in the individual consumption tax do not have much impact on the progressivity of the tax system, as some items such as perfume can hardly be considered as luxuries anymore. In any case, using a complicated system of excises is not the most efficient means of achieving equity objectives. Instead, excises should be focused on addressing externalities rather than on raising revenue. This suggests limiting excises to products such as tobacco and liquor for health reasons and to energy for environmental reasons, with the rate based on the size of the externality (Box 1), while eliminating the other excises.

\section{Box 1. Environmentally-related taxes}

Environmentally-related taxes are another way to broaden the tax base, while avoiding the distortions inherent in income taxes and improving welfare. Environmental taxes in Korea have risen to almost 3\% of GDP, slightly above the OECD average (Figure 13), reflecting a tripling of the tax on diesel between 2001 and 2007. In addition, the proportion of the revenue from the transportation-energy-environment tax that is earmarked for transport infrastructure, primarily roads, was reduced from $86 \%$ to $80 \%$ in 2007 , and $15 \%$ was earmarked for environmental improvement.

Figure 13. International comparison of environmentally-related taxes Revenue as a per cent of GDP

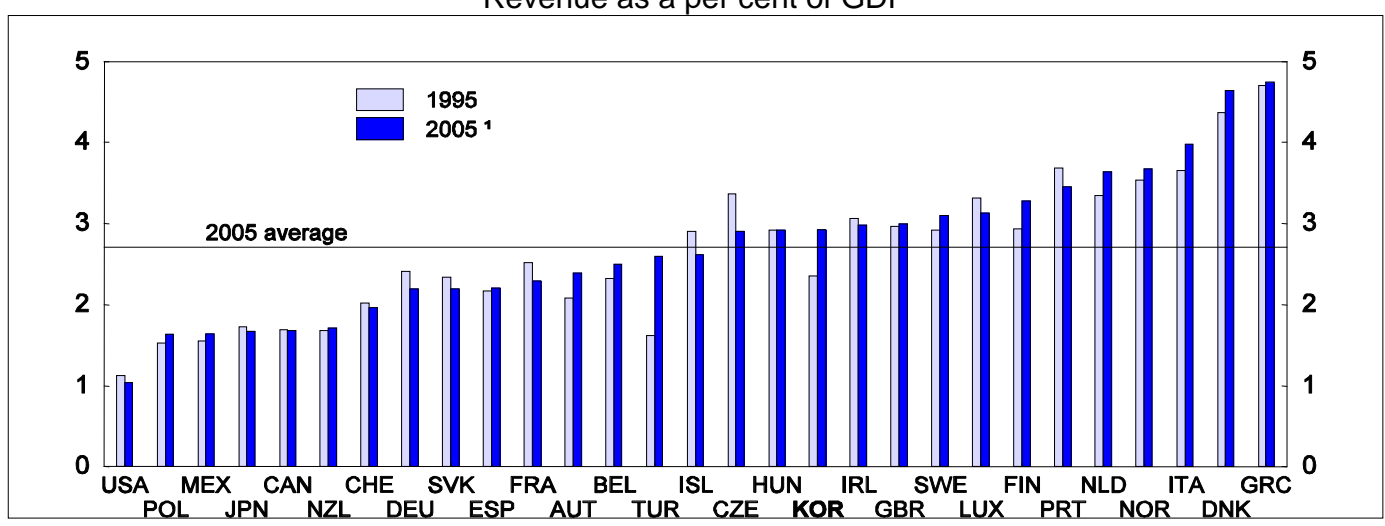

1. 2005 data not available in the case of France and Iceland (2004 data used) and Korea (2003 data).

Source: OECD (2008c), Revenue Statistics 1965-2007, OECD, Paris (http://dx.doi.org/10.1787/366725334503).

Higher energy taxes have helped slow the growth of energy consumption and reduce air pollution. A 
comprehensive air quality plan in 2005 for the Seoul metropolitan area targets a further $41 \%$ to $47 \%$ cut in pollutant emissions by 2014 through several measures. First, for stationary sources, the cut in emissions is to be achieved through a total pollution load management and emission trading ("cap and trade") system introduced in the capital region in 2007 for SOx, NOx and TSP. It was initially applied to large sources and will be extended to mid-sized sources in 2009. Second, a wide range of measures are being implemented to reduce emissions and energy consumption by on-road mobile sources, the major emission source in Seoul. These measures include tighter emission standards, inspections, stronger fuel standards and the use of low-emission vehicles in the public sector.

Greater use of economic instruments to address the externalities of pollution and congestion would allow a liberalisation of the regulations currently used to limit the concentration of population in the Seoul metropolitan region. The construction of large-scale facilities, including factories and universities, is still prohibited or controlled by regulations dating back to the 1960s. Their effectiveness is reduced by a number of exceptions that have been introduced, such as those for SMEs, venture businesses, FDI and advanced-technology firms. Despite the regulations, the capital region's share of the population has risen from $18 \%$ in the 1980 s to nearly half. Moreover, the regulatory approach to limit concentration has a number of negative side effects. First, the policies are holding back Seoul's international competitiveness. In an increasingly globalised economy, firms that are not allowed to invest in the Seoul region may invest instead in other countries. Second, addressing negative externalities by imposing restrictions on the location of certain economic activities is a costly approach as enterprises that would benefit the most from locating in the capital region are often excluded, while the possibility of obtaining exemptions to restrictions prompts lobbying.

The taxation of energy should be improved. First, the earmarking of the transportation-energy-environment tax, which is subject to a 2009 sunset clause, should be ended. Allocating $80 \%$ of the revenue from energy taxes to the transport sector undermines the effectiveness of those taxes. Second, the tax should be converted to a tax on energy consumption, phasing out exemptions and reductions for energy-intensive sectors and activities. There is considerable scope to increase fuel efficiency. Indeed, the energy-to-GDP ratio in Korea is the sixth highest in the OECD area. However, one concern in Korea is that boosting taxes on energy consumption will reduce the international competitiveness of energy-intensive sectors. Third, the government should not reduce energy taxes to offset the impact of higher oil prices, as it did in March 2008 when the gasoline tax was cut by $10 \%$ (the government promised more cuts if the price of oil were to reach $\$ 170$ per barrel). A 10 trillion won (1\% of GDP) package announced in June 2008 included fuel subsidies for truckers, farmers and fishermen. Only by allowing the right price signals to affect demand and supply can better balance be established in these markets. Concern about the living standards of lowincome households is better addressed through taxes and social transfers. The June 2008 package is to provide such assistance through income tax rebates, although more than one-half of workers are eligible for rebates.

Another challenge is to reduce the level of greenhouse gas emissions. Korea, which was classified as a developing country in the 1997 Kyoto Protocol and thus exempted from mandatory cuts, is the world's tenth-largest source of greenhouse gas emissions, as its emissions almost doubled between 1990 and 2005. The Environment Ministry announced in March 2008 that it would seek to cap emissions at the 2005 level by 2012 by encouraging the use of environment-friendly vehicles and fuels, and staging nationwide energy-saving campaigns. The official reduction target, though, has not yet been set. To cut emissions, the government is considering the introduction of tax benefits for investment in emission reduction and a carbon tax, which taxes the combustion of fossil fuels according to their carbon content. A number of OECD countries, including the United Kingdom and the Netherlands, have introduced instruments that have elements of a carbon tax. Higher taxes on greenhouse gas-emitting activities would also provide scope for reducing more distortive taxes on income.

1. Carbon taxes may need to be accompanied by permit trading. Both approaches have their pros and cons. A permit system gives certainty about emissions at the price of uncertainty about the costs, whereas a tax has the opposite effect. Taxes may entail smaller administrative costs and could be technically easier to implement in developing countries, but tradable permits build up a stronger political constituency (permit holders) with an interest in enforcing the policy in the future.

45. Simplifying the system of excises should be accompanied by a phasing-out of earmarked taxes, which accounted for $14 \%$ of total tax revenue in 2007 . The education tax, for example, is financed by surcharges on tobacco, liquor and the individual consumption tax. Earmarking is used in some countries as a political tool to foster public support for tax increases to cover specific expenditures. It can allow a closer link between those who pay the tax and those who benefit, although the connection between taxpayers and beneficiaries is quite weak in Korea ${ }^{31}$ However, earmarking has a number of disadvantages. First, it reduces the flexibility of policymakers to adjust spending as expenditure needs change over time. Second, when earmarked revenues exceed the expenditures for which they are targeted, it can be difficult to

31. For example, the link between taxes on tobacco and liquor and education spending is not obvious. 
reallocate the additional funds to other more productive purposes, encouraging excessive spending in the targeted area. Third, earmarked taxes significantly increase the complexity of the tax system. Fourth, earmarking nurtures vested interests within and outside the government. In sum, reducing earmarking would promote the efficient management of public finances. Given the negative aspects of earmarking, the government has announced a plan to eliminate the three national earmarked taxes (education, local development and transport-energy-environment) in 2010 and integrate them into other taxes.

\section{Improving the local tax system}

46. One proposal to increase local government tax revenue is to create a local VAT with a $2 \%$ rate, with an offsetting cut in the national rate to $8 \%$, leaving the overall rate at $10 \%$. The central government would collect the tax and allocate it to local governments based on consumption patterns. Although a local VAT would transfer more revenue to local governments, it would not increase their autonomy. The need for more local government revenue is not pressing at the moment. Indeed, the hike in the Local Share Tax from $15 \%$ of national internal taxes to $19.2 \%$ has increased local government revenue and reduced their borrowing. If the additional revenue from a local VAT were offset by a reduction in the Local Share Tax, which is allocated so as to reduce regional inequality, it would have adverse implications for equity.

\section{Property taxes}

\section{Overview of property taxes}

47. Property-related taxes are high in Korea, at 3.5\% of GDP in 2006 compared with an OECD average of $2.0 \%$. However, their prominent role is primarily due to taxes on transactions $-2.4 \%$ of GDP, the highest in the OECD area - which hamper mobility by creating lock-in effects. The government reduced property transaction taxes by cutting the rate on acquisitions from $2.2 \%$ in 2004 to $1.1 \%$ in 2007 and the rate on registrations from $3.6 \%$ to $1.2 \% .^{32}$ As for capital gains, single homeowners are not taxed on the sale of houses owned at least three years and valued at less than 600 million won $(\$ 409000)$. As a result, less than $2 \%$ of households are subject to capital gains taxes. The thresholds are similar to those of the PIT while the tax rates are one percentage point higher. However, a uniform rate of $40 \%$ is applied to property held between one and two years, and 50\% for that held less than one year (Table 7). In recent years, the government has strengthened capital gains taxes as part of its effort to stabilise housing prices and increase income redistribution. First, actual sales prices are used to calculate capital gains, ${ }^{33}$ rather than the value assessed by the National Tax Service, which is $50 \%$ to $70 \%$ of the market value. Second, the government has focused higher capital gains taxes on persons who own more than one dwelling. A rate of 50\% was imposed in 2007 on persons with two houses and a rate of $60 \%$ on those owning three or more. ${ }^{34}$

48. In contrast to transaction taxes, taxes on property holding were much lower at $0.5 \%$ of GDP in 2005. However, there was a major overhaul of property taxes that year. The local taxes on structures (six rates between $0.3 \%$ and $7 \%$ ) and on land (nine rates between $0.2 \%$ and $5 \%$ ) were combined. The new local

32. The combined rate has thus fallen from $5.8 \%$ to $2.3 \%$ for transactions between individuals. For other transactions, the combined rate is $4.6 \%$ (2.2\% for the acquisition tax and $2.4 \%$ for the registration tax).

33. The use of the actual sales price was introduced for houses valued at more than 600 million won in 1999, households owning three or more houses in 2004 and households owning two or more houses in 2006.

34. The 50\% rate was introduced in 2007 and the $60 \%$ rate in 2005 . A normal tax rate of $8 \%$ to $35 \%$ is applied to those who rent five or more houses if: $i$ ) they are all located in the same city or county; ii) they have been rented at least ten years; iii) the size of each rented house is 85 square metres or less; and $i v$ ) the value of each rented house does not exceed 300 million won (as assessed by the government) at the time of sale. 
tax on property has three rates, ranging from $0.15 \%$ to $0.5 \%$ (Table 8 ). In addition, the evaluation of real estate values for tax purposes was brought closer into line with market values. The evaluation was raised from 36\% (the so-called "application ratio") of the value of the house as assessed by the Ministry of Construction and Transportation (MCT) to 50\%. Given that the MCT's assessed value is about $80-90 \%$ of the market price, the tax base has risen from about $29-32 \%$ of the market value to $40-45 \%$.

49. The changes in the local property tax were accompanied by the introduction in 2005 of the CPT, a national tax applied to households and firms owning housing with a combined assessed value exceeding 900 million won. The threshold was subsequently reduced to 600 million won. In 2006, $1.3 \%$ of households were subject to this tax, whose revenues are transferred to local governments to reduce regional inequalities, based on a formula that gives an $80 \%$ weight to their fiscal needs. The CPT is very progressive with rates from $1 \%$ to $3 \%$. Its top rate is thus 20 times higher than the lowest rate of local property tax on households, which is set at $0.15 \%$. Thus, the burden on CPT-payers is very heavy, even though the overall burden of property-holding tax is rather low in Korea. In contrast, most OECD countries impose a flat rate, or moderately progressive rates, on property holding.

Table 7. Recent changes in the capital gains tax on property

\begin{tabular}{|c|c|c|c|}
\hline Situation & Tax rates through end-2006 & Tax rates from 2007 & $\begin{array}{l}\text { Tax rates from } \\
2010\end{array}$ \\
\hline Normal tax rates ${ }^{1}$ & $\begin{array}{c}9 \% \text { to } 36 \% \text { depending on the } \\
\text { size of the gain }\end{array}$ & No change & $\begin{array}{c}6 \% \text { to } 33 \% \\
\text { depending on the } \\
\text { size of the gain }\end{array}$ \\
\hline Owned less than 1 year & $50 \%$ & No change & No change \\
\hline Owned 1 to 2 years & $40 \%$ & No change & No change \\
\hline Unregistered property & $70 \%$ & No change & No change \\
\hline Households owning 3 or more houses ${ }^{2}$ & $60 \%$ & No change & No change \\
\hline Households owning 2 houses $^{2}$ & Normal tax rate $(9-36 \%)$ & $50 \%$ & No change \\
\hline Land held for non-business purposes & Normal tax rate $(9-36 \%)$ & $60 \%$ & No change \\
\hline
\end{tabular}

1. Applies to households with one house with a selling price of more than 600 million won (about $\$ 409$ 000), which accounts for $2-3 \%$ of total houses in Korea (the threshold is to be raised to 900 million won in 2010). The taxable gain is calculated as: [(S 600 million $) / S]^{*}(S-P)$, where $S$ is the selling price and $P$ is the purchase price. Thus, if the selling price were 1.8 billion won and the purchase price were 1 billion won, the taxable gain would be 0.53 billion won.

2. In addition, the special deduction in the capital gains tax for long-term ownership, which can go as high as $30 \%$, was eliminated for multiple homeowners in 2007.

Source: Ministry of Strategy and Finance.

\section{Promoting economic growth}

50. A tax on property holding is more favourable for growth than other taxes as it has less impact on decisions to supply labour, produce, invest and innovate (Johansson et al., 2008). Increasing the share of property tax in the overall tax mix would reduce the need for other more distorting taxes, in addition to promoting the efficient use of land. However, the introduction of the CPT proved problematic for a number of reasons (see below). Higher holding taxes should be accompanied by a reduction in transaction taxes. The planned reform of the capital gains tax in 2010 -- by raising the threshold for single homeowners to 900 million won (\$613 000) and bringing the rates into line with the PIT -- is a positive step in this regard as it will reduce the lock-in effect that blocks the supply of houses (Kim, 2005). Indeed, the low level of property transactions during the past year appears to be partly related to the increased taxation of capital gains introduced in 2006-07. 


\section{Ensuring adequate revenue}

51. Following the changes in the valuation of real estate for the local property tax and the introduction of the CPT, the total tax on holding property rose to $0.8 \%$ of GDP in 2006. It is still well below the OECD (weighted) average of almost 2\% (Figure 14), indicating scope to further increase property taxes toward the levels in the most advanced countries in order to meet future revenue needs. A higher effective rate should be achieved by gradually raising the overall holding tax, rather than through the CPT, which led to a sudden increase on a small group of taxpayers. Moreover, the CPT was aimed at controlling short-term fluctuations in housing prices and redistributing income (OECD Economic Surveys: Korea, 2007). Property taxes should instead be based on a long-term perspective of efficiency considerations and government revenue needs. Given that housing prices are determined by many factors, including macroeconomic conditions and regulations, using tax policy to influence house prices in the short run is unlikely to be successful and will result in a sub-optimal tax policy.

Table 8. Property holding taxes in Korea

\begin{tabular}{|c|c|c|c|c|c|c|}
\hline & \multicolumn{3}{|c|}{ Local property tax } & \multicolumn{3}{|c|}{ National Comprehensive Property Tax ${ }^{\top}$} \\
\hline & Housing & $\begin{array}{l}\text { Land for } \\
\text { business }\end{array}$ & $\begin{array}{c}\text { Land for } \\
\text { non- } \\
\text { business }\end{array}$ & Housing & $\begin{array}{l}\text { Land for } \\
\text { business }\end{array}$ & $\begin{array}{l}\text { Land for } \\
\text { non- } \\
\text { business }\end{array}$ \\
\hline Asset value threshold (won) & 0 & 0 & 0 & $\begin{array}{l}600 \text { million } \\
\text { (900 million) }\end{array}$ & $\begin{array}{c}4 \text { billion } \\
\text { ( } 8 \text { billion) }\end{array}$ & $\begin{array}{c}300 \text { million } \\
\text { (500 million) }\end{array}$ \\
\hline Calculation of tax base & $\begin{array}{l}\text { Per } \\
\text { property }\end{array}$ & $\begin{array}{c}\text { Cumulative } \\
\text { value per } \\
\text { person }\end{array}$ & $\begin{array}{c}\text { Cumulative } \\
\text { value per } \\
\text { person }\end{array}$ & $\begin{array}{l}\text { Nationwide } \\
\text { cumulative } \\
\text { value per } \\
\text { household }\end{array}$ & $\begin{array}{l}\text { Nationwide } \\
\text { cumulative } \\
\text { value per } \\
\text { person }\end{array}$ & $\begin{array}{l}\text { Nationwide } \\
\text { cumulative } \\
\text { value per } \\
\text { household }\end{array}$ \\
\hline Tax rates $^{2}$ & $0.15-0.5 \%$ & $0.2-0.4 \%$ & $0.2-0.5 \%$ & $\begin{array}{c}1-3 \% \\
(0.5-1.0 \%)\end{array}$ & $\begin{array}{c}0.6-1.6 \% \\
(0.5-0.7 \%)\end{array}$ & $\begin{array}{c}1-4 \% \\
(0.75-2 \%)\end{array}$ \\
\hline $\begin{array}{l}\text { Ceiling on increase in tax } \\
\text { payment }{ }^{3}\end{array}$ & $\begin{array}{l}105 \text { to } \\
150 \%\end{array}$ & $150 \%$ & $150 \%$ & $\begin{array}{l}300 \% \\
(150 \%)\end{array}$ & $150 \%$ & $\begin{array}{l}300 \% \\
(150 \%)\end{array}$ \\
\hline Application ratio ${ }^{4}$ & $50 \%$ & $60 \%$ & $60 \%$ & $80 \%$ & $60 \%$ & $80 \%$ \\
\hline $\begin{array}{ll}\text { 1. } & \text { Changes announce } \\
\text { 2. } & \text { There are three tax } \\
\text { 3. } & \text { Relative to the prece } \\
\text { 4. } & \text { The proportion of th } \\
\text { Source: } & \text { Ministry of Strategy and }\end{array}$ & $\begin{array}{l}\text { September } \\
\text { es for each ca } \\
\text { hg year. } \\
\text { alue assesse } \\
\text { nance. }\end{array}$ & $\begin{array}{l}\text { are shown } \\
\text { ory except th } \\
\text { the Ministry }\end{array}$ & $\begin{array}{l}\text { rentheses. } \\
\text { mprehensiv } \\
\text { onstruction }\end{array}$ & $\begin{array}{l}\text { perty Tax on } \\
\text { ransport that }\end{array}$ & $\begin{array}{l}\text { sing, which } h \\
\text { sed as the ta }\end{array}$ & our. \\
\hline
\end{tabular}

52. The government's plan to revise the CPT by reducing the rates to $0.5 \%$ to $1 \%$, raising the threshold for paying the tax to 900 million won and freezing the "application ratio" is thus appropriate and should allow an increase in property-holding taxes in the medium term. As with the highly progressive rate structure of local property taxes in the past, the CPT makes it difficult to raise the average tax on holding property from its relatively low level. Moreover, given that income redistribution is not the role of local governments, they avoided relying on the highly progressive local property tax as a revenue source, limiting it to only $8 \%$ of their revenue. The introduction of the CPT in 2005 continues to limit the scope for local authorities to raise the local property tax.

35. In addition, the Supreme Court ruled in November 2008 that some aspects of the CPT are unconstitutional. 
Figure 14. International comparison of taxes on immovable property As a per cent of GDP in 2006

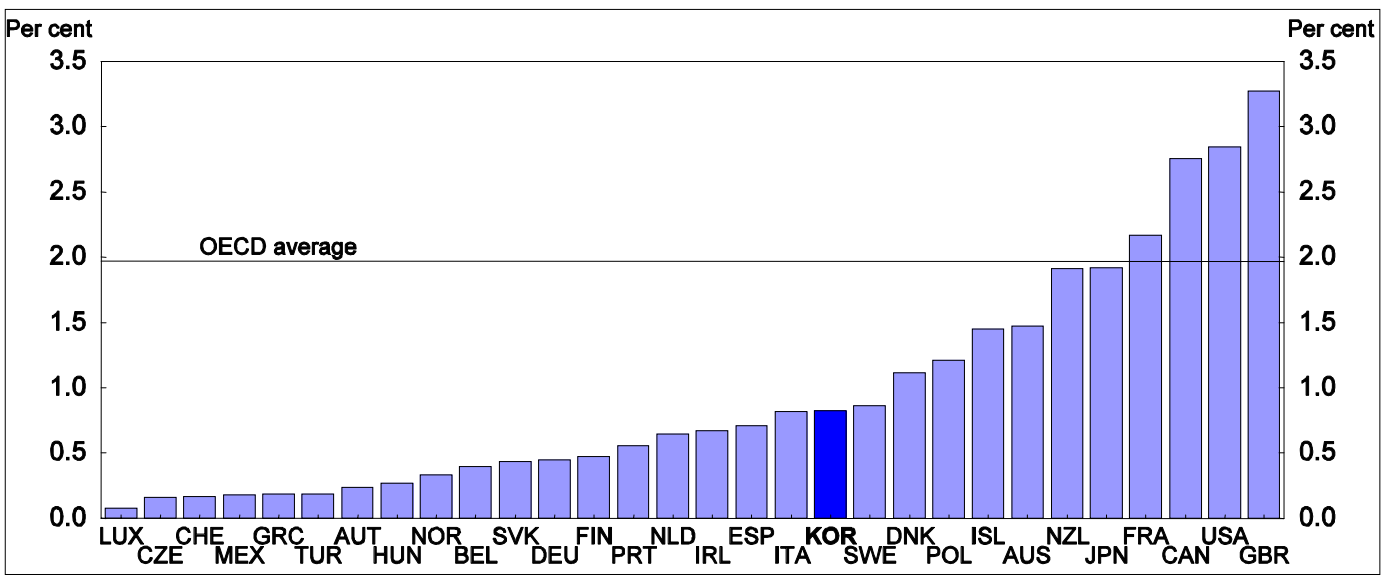

Source: OECD (2008c), Revenue Statistics 1965-2007, OECD, Paris (http://dx.doi.org/10.1787/366725334503).

\section{Coping with income inequality}

53. Although recent changes in property taxation are aimed at improving income equality, they raise several problems. Regarding capital gains, the wide variation in tax rates applied to gains of similar size creates equity issues. For example, the owner of five or more dwellings can be treated as a rental business and subject to tax rates ranging from $9 \%$ to $36 \%$, while the owner of three or four dwellings pays $60 \%$. The tax should be based on the size of the capital gain rather than on the number of houses owned (Kim, 2007). As for property holding taxes, the emphasis on redistribution conflicts with the benefit principle, which states that local taxes should reflect the use of local public services rather than the ability to pay. Moreover, relying on real estate taxes for redistribution is inappropriate as it does not include other forms of wealth. Consequently, persons holding real estate are taxed more heavily than those who invested in other assets. While housing ownership in Korea does increase with income, the relationship between household income and housing wealth is not strong, thus reducing the effectiveness of property tax in reducing income inequality (Sung and Kim, 2008 and Ro, 2007).

\section{Improving the local tax system}

54. Providing local governments with sufficient revenue-raising autonomy to make them accountable to local citizens and encourage fiscal discipline is important to improve efficiency and welfare. As noted above, there are drawbacks to using direct taxes and consumption taxes to finance local governments in Korea. In contrast, a tax on property holding has a number of desirable properties: it is visible, imposes discipline on local authorities and is relatively resistant to tax-base flight. In most OECD countries, property tax is a purely local tax, reflecting its advantages as a source of finance for local governments. However, the use of a national property holding tax in Korea limits the scope for using local property taxes and increasing the autonomy of local governments. Moreover, imposing both national and local taxes on property holding is a possible source of confusion. The government's planned revision of the CPT should be a first step toward phasing it out over the medium term and thereby allowing a larger role for local property taxes.

55. One rationale for introducing a national property tax was the tendency of some revenue-rich local governments to cut their local property tax rates, thereby undermining the central government's objective of raising the effective tax rate on property. Such an outcome reflects the increasing revenue of local governments in the capital region, which has half of the country's population, and their lack of spending responsibilities. Indeed, major services such as education and police services are funded primarily by the 
central government. The objective of raising the effective rate of property tax is thus linked to the issue of fiscal decentralisation and the need for a greater local government role in providing public services.

\section{Improving the administration of the tax and social insurance systems}

56. Upgrading the management of tax and social insurance contributions is important to expand the coverage of the social safety net and reduce the cost of compliance. Korea's social security system has developed gradually with the introduction of insurance for industrial accidents (1964), medical care (1977), pensions (1988), employment (1995) and long-term care (2008). Each insurance system has evolved independently, with a lack of close co-ordination with the other systems, especially in terms of collecting contributions. The collection processes differed in terms of the definition of the wage base, the payment intervals, end-year adjustments, employer ID codes and other features. ${ }^{36}$ Separate collection has been administratively costly for the government, while differences in the base and timing have prevented the sharing of information and cross-checks between the different systems.

57. These problems have contributed to low insurance coverage, particularly for non-regular workers and employees at small firms. While three-quarters of regular workers were covered by pension and medical insurance at their workplace in 2005 and two-thirds by employment insurance, the share was only around $40 \%$ for non-regular workers (Table 9). At small firms, only a quarter of regular workers and less than $10 \%$ of non-regular workers were covered. With existing manpower, the social insurance systems and the NTS do not have the capacity to enforce compliance by non-regular workers and small firms. Low levels of compliance hinder the capacity of the social insurance schemes to achieve their intended goals. For example, the gaps in the coverage of employment insurance help to explain why only one-third of unemployed persons receive benefits. Moreover, lower social insurance contributions encourage firms to hire non-regular workers, who now account for more than one-third of employment (see the 2008 OECD Economic Surveys: Korea).

58. A number of reforms were introduced in 2005. First, the wage bases of all contribution schemes were aligned on taxable income, which firms are required to report to the tax authorities each year, thus reducing the cost of verifying income. Second, contributions are based on the previous year's income and the contribution amount is calculated by the insurers. Third, a common system of ID codes for workplaces was developed. In addition, the NTS now requires firms to report the payroll of temporarily employed and contingent employees. Legislation to create a single agency in 2009 for the collection of social insurance payments, under the direction of the NTS, failed to pass the National Assembly, in part due to opposition from SMEs who feared that it would substantially increase their payments. The creation of a unified collection agency is a necessary condition to significantly expand the coverage of social insurance.

36. The Ministry of Health and Welfare administers health, long-term care and pension insurance, while the Ministry of Labour manages the industrial accident insurance and the Employment Insurance System. The medical insurance contribution is based on the "standard monthly income", the pension contribution on the "standard monthly wage" and industrial accident and employment insurance contributions on total wages. 
Table 9. Coverage of the social insurance systems by type of worker ${ }^{1}$

\begin{tabular}{c|lllll}
\hline Regular workers (per cent of total) & 2003 & 2004 & 2005 & 2006 & 2007 \\
\hline National pension & 70.8 & 72.5 & 75.7 & 76.1 & 76.3 \\
National health insurance & 72.5 & 73.8 & 75.9 & 76.1 & 76.7 \\
Employment insurance & 59.7 & 61.5 & 63.8 & 64.7 & 64.3 \\
\hline Non-regular workers (per cent of total) & & & & & \\
\hline National pension & 30.5 & 37.5 & 36.6 & 38.2 & 40.0 \\
National health insurance & 32.6 & 40.1 & 37.7 & 40.0 & 42.5 \\
Employment insurance & 29.2 & 36.1 & 34.5 & 36.3 & 39.2 \\
\hline
\end{tabular}

1. This survey-based data does not match the records of the social insurance systems. For example, while the number of workers covered by the EIS based on the survey is around 8 million, the Ministry of Labour reported that more than 9 million were covered in 2007.

Source: Korea National Statistics Office, "Supplementary Survey on Economically Active Population".

59. This would also ease compliance costs for firms. According to a study by the World Bank, complying with labour taxes, including social security contributions, requires 120 hours a year for firms in Korea, more than triple the OECD average (Figure 15). The time needed for corporate income taxes is also about three times higher than the OECD average. Although the time necessary to comply with the VAT is relatively low, the total for the three taxes sums to 270 hours per year, almost double the OECD average. Simplifying the tax system is thus an important objective on efficiency grounds. In addition, it would weaken the incentive for tax planning, which imposes deadweight losses.

Figure15. Simplicity of tax systems

Hours required to comply with tax obligations, 2006

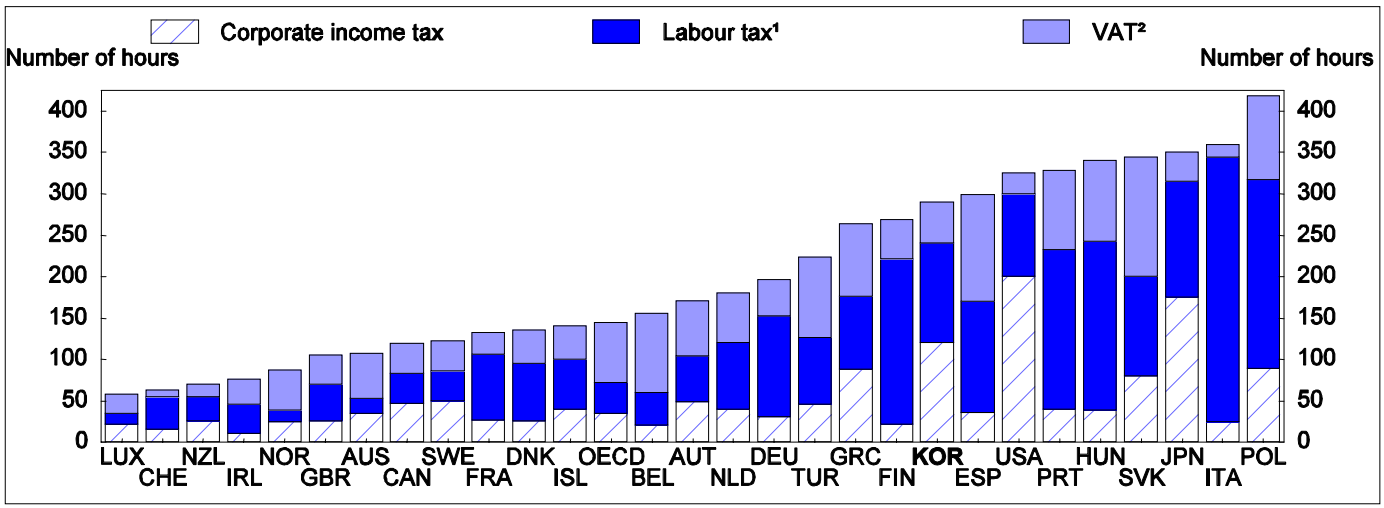

1. Including social security contributions.

2. Including consumption taxes.

Source: The World Bank (2008), Paying Taxes 2008.

\section{Directions for tax reform}

60. Korea's immediate challenge is to improve its tax system and tax administration to sustain economic growth while achieving distributional objectives and increasing the gains from decentralisation. Such reforms will make it easier to meet the second challenge of upward pressure on public spending in the context of rapid population ageing. Specific recommendations are reported in Table 10. From a political economy perspective, fundamental tax reform is never easy. In Korea, there has been stiff resistance to higher tax and contribution rates. For example, to ensure the financial sustainability of the National Pension Scheme, the government proposed in 2003 to raise the contribution rate from 9\% to $15.9 \%$ by 2030 , while cutting the replacement rate from $60 \%$ to $50 \%$. However, this reform was rejected in favour of leaving the contribution rate at $9 \%$ and cutting the replacement rate to $40 \%$. This reform did 
not ensure long-run financial sustainability, which would require a contribution rate of $12.9 \%$, or an even larger cut in the replacement rate.

61. Among the reforms proposed in this paper, the recommendation to lower the corporate tax rate while broadening the PIT base may be unpopular. It is important to note that the CIT is borne not only by shareholders, but also by workers through reduced wages and lower employment, suggesting that a cut in the corporate rate would boost household income. Indeed, a study of the United Kingdom found that workers bear about half of the corporate tax burden in the short run and all of it in the long run (Arulampalam et al., 2007).

62. Implementing a comprehensive tax reform requires clear communication of the plan and its objectives, based on transparent and well-articulated principles, so that taxpayers understand what the government is trying to achieve. This should include the following points:

- The authorities should demonstrate their commitment to improving the efficiency of spending before asking the public to pay higher taxes. The plan to privatise some state-owned enterprises and increase the efficiency of public organisations is useful in this regard.

- It is important to recognise that the tax burden in Korea is one of the lowest in the OECD area due to its relatively low level of income per capita and young population. As Korea's income level converges to the OECD average and as rapid population ageing makes it one of the oldest countries in the OECD, it will be difficult to maintain such a low share of taxes in GDP.

- The reform must be fair to the extent possible across different segments of the population. In particular, it is essential that the broadening of the tax base also includes the self-employed, thus avoiding an unfair burden on salaried workers.

- Nearly all OECD countries have launched substantial tax reforms in recent years, driven by the need to provide a fiscal environment that is more conducive to investment, risk-taking and work incentives (OECD, 2004). While Korea's tax system has many pro-growth features, it is important to avoid falling behind in an increasingly integrated and competitive world economy.

- The proposed tax reform should address emerging concerns about inequality primarily by expanding the EITC. Such an approach would avoid increasing the rates of the personal income tax, which tends to discourage human capital formation and labour supply. 
ECO/WKP(2009)12

Table 10. Summary of recommendations for tax reform

\begin{tabular}{|c|c|c|c|c|}
\hline & Promoting growth & Raising revenue & Reducing inequality & $\begin{array}{l}\text { Improving the local } \\
\text { government tax system }\end{array}$ \\
\hline $\begin{array}{l}\text { Corporate income } \\
\text { tax }\end{array}$ & $\begin{array}{l}\text { Lower the statutory tax rate on } \\
\text { firms to promote Korea's } \\
\text { international competitiveness } \\
\text { - Reduce the share of corporate } \\
\text { taxes in total direct taxes } \\
\text { - Phase out quasi-taxes }\end{array}$ & $\begin{array}{l}\text { Broaden the tax base by } \\
\text { reducing tax } \\
\text { expenditures }\end{array}$ & & $\begin{array}{l}\text { Avoid reliance of local } \\
\text { governments on corporate } \\
\text { taxes given their volatility } \\
\text { and the large gap between } \\
\text { jurisdictions }\end{array}$ \\
\hline $\begin{array}{l}\text { Personal income } \\
\text { tax }\end{array}$ & $\begin{array}{l}\text { - Increase the share of personal } \\
\text { income tax in total direct taxes } \\
\text { - Reduce the preferential treatment } \\
\text { of retirement allowances } \\
\text { - Cut tax rates to promote FDI, } \\
\text { entrepreneurship and education }\end{array}$ & $\begin{array}{l}\text { - Broaden the personal } \\
\text { income tax base } \\
\text { - Further increase } \\
\text { compliance of the self- } \\
\text { employed by improving } \\
\text { enforcement and hiking } \\
\text { penalties for tax evasion }\end{array}$ & $\begin{array}{l}\text { Expand the earned } \\
\text { income tax credit } \\
\text { introduced in } 2008 \\
\text { - Increase the } \\
\text { taxation of fringe } \\
\text { benefits }\end{array}$ & $\begin{array}{l}\text { Encourage local } \\
\text { governments to use their } \\
\text { existing authority to change } \\
\text { local income tax rates to } \\
\text { increase local government } \\
\text { revenue and autonomy }\end{array}$ \\
\hline $\begin{array}{l}\text { Value-added tax } \\
\text { and other } \\
\text { consumption taxes }\end{array}$ & $\begin{array}{l}\text { - Rely on the VAT for increased } \\
\text { revenue and reduce the share from } \\
\text { more distortive taxes } \\
\text { - Maintain a unified VAT rate and a } \\
\text { broad base to limit distortions } \\
\text { - Phase out individual consumption } \\
\text { taxes unless they are justified by } \\
\text { health or environmental concerns } \\
\text { - Phase out earmarked taxes }\end{array}$ & $\begin{array}{l}\text { - } \text { Raise the VAT rate } \\
\text { - Further broaden the } \\
\text { base by reducing special } \\
\text { treatment of SMEs } \\
\text { - Strengthen } \\
\text { environmentally-related } \\
\text { taxes }\end{array}$ & $\begin{array}{l}\text { Avoid lower VAT } \\
\text { rates on daily } \\
\text { necessities as these } \\
\text { tend to benefit } \\
\text { higher-income } \\
\text { persons }\end{array}$ & $\begin{array}{l}\text { Avoid a local VAT as it } \\
\text { would widen the gap in } \\
\text { fiscal capacity between } \\
\text { regions while failing to } \\
\text { enhance local government } \\
\text { autonomy }\end{array}$ \\
\hline Property taxes & $\begin{array}{l}\text { - Increase local property holding } \\
\text { taxes, thereby reducing reliance on } \\
\text { more distortive taxes and } \\
\text { promoting efficient land use } \\
\text { - Further reduce taxes on } \\
\text { transactions to promote mobility } \\
\text { and reduce lock-in effects }\end{array}$ & $\begin{array}{l}\text { - Increase local taxes on } \\
\text { property holding, thus } \\
\text { offsetting declining } \\
\text { revenue from transaction } \\
\text { taxes }\end{array}$ & $\begin{array}{l}\text { Base the capital } \\
\text { gains tax on the size } \\
\text { of the gain rather } \\
\text { than the number of } \\
\text { houses owned }\end{array}$ & $\begin{array}{l}\text { - Increase the scope for local } \\
\text { property holding taxes by } \\
\text { phasing out the CPT over } \\
\text { the medium term }\end{array}$ \\
\hline
\end{tabular}




\section{Bibliography}

Arulampalam, W., M. Devereux and G. Maffini (2007), “The Incidence of Corporate Income Tax on Wages", Oxford University Centre for Business Taxation Working Paper No. 07/07, Oxford.

Bassanini, A. and R. Duval (2006), "The Determinants of Unemployment Across OECD Countries: Reassessing the Role of Policies and Institutions", OECD Economic Studies, No. 42, OECD, Paris.

Bassanini, A., J. Rasmussen and S. Scarpetta (1999), "The Economic Effects of Employment-Conditional Income Support Schemes for the Low-Paid: An Illustration from a CGE Model Applied to Four OECD Countries", OECD Economics Department Working Paper No. 224, OECD, Paris.

Bassanini, A. and S. Scarpetta (2001), "The Driving Forces of Economic Growth: Panel Data Evidence for the OECD Countries", OECD Economic Studies, No. 33, OECD, Paris.

Causa, O. (2008), "Explaining Differences in Hours Worked Among OECD Countries: An Empirical Analysis", OECD Economics Department Working Paper No. 596, OECD, Paris.

De Mooij, R. and S. Ederveen (2003), "Taxation and Foreign Direct Investment: A Synthesis of Empirical Research", International Tax and Public Finance, No. 10.

European Commission (2006), Structures of the Taxation Systems in the European Union, Brussels.

Hajkova, D., G. Nicoletti, L. Vartia and K. Yoo (2006), "Taxation, Business Environment and FDI Location in OECD Countries", Economics Department Working Paper No. 502, OECD, Paris.

Jaumotte, F. (2003), "Labour Force Participation of Women: Empirical Evidence on the Role of Policy and Other Determinants in OECD Countries, OECD Economic Studies, No. 37, OECD, Paris.

Jaumotte, F. and N. Pain (2005), "Innovation in the Business Sector", OECD Economics Department Working Paper No. 459, OECD, Paris.

Johansson, Å., C. Heady J. Arnold, B. Brys and L. Vartia (2008), “Tax end Economic Growth”, OECD Economics Department Working Paper No. 620, OECD, Paris.

Kim, Junghun (2005), “Tax Reform Issues in Korea”, Journal of Asian Economics, Vol. 16.

Kim, Kyung Hwan (2007), "On Reforming the Taxation of Housing in Korea", Research on Expert Assessment, Vol. 17, No. 2, Korea Real Estate Research Institute, Seoul (in Korean).

KRILA (Korea Research Institute for Local Administration) (2007), Local Government in Korea, Seoul.

Mintz, J. (2007), 2007 Tax Competitiveness Report, C.D. Howe Institute, Toronto, Canada.

OECD (2003), OECD Employment Outlook, OECD, Paris.

OECD (2004), "Recent Tax Policy Trends and Reforms in OECD Countries", OECD Tax Policy Studies No. 9, OECD, Paris.

OECD (2005a), OECD Economic Surveys: Korea, OECD, Paris.

OECD (2005b), OECD Territorial Reviews: Busan, Korea, OECD, Paris. 
OECD (2006a), OECD Employment Outlook, OECD, Paris.

OECD (2006b), OECD Environmental Performance Reviews: Korea, OECD, Paris.

OECD (2006c), "Fundamental Reform of Personal Income Tax", OECD Tax Policy Studies No. 13, OECD, Paris.

OECD (2007a), OECD Economic Surveys: Korea, OECD, Paris.

OECD (2007b), OECD Employment Outlook, OECD, Paris.

OECD (2007c), Taxing Wages 2006/2007, OECD, Paris.

OECD (2008a), Consumption Tax Trends, OECD, Paris.

OECD (2008b), Growing Unequal? Income Distribution and Poverty in OECD Countries, OECD, Paris.

OECD (2008c), Revenue Statistics, OECD, Paris (http://dx.doi.org/10.1787/366725334503).

OECD (2008d), Science, Technology and Industry Scoreboard, OECD, Paris.

OECD (2008e), Tax Database, OECD, Paris (www.oecd.org/ctp/taxdatabase).

Oliveira Martins, J., R. Boarini, H. Strauss, C. de la Maisonneuve and C. Saadi (2007), "The Policy Determinants of Investment in Tertiary Education", OECD Economics Department Working Paper No. 576, OECD, Paris.

Ro, Younghoon (2007), The Real Estate Market and Real Estate Tax Policy, Korea Institute of Public Finance, Seoul (in Korean).

Sung, Myung Jae and Hyunsook Kim (2008), "Estimation of Joint Distribution of Income and Real Assets and Related Tax Burdens" (in Korean).

Sung, Myung Jae and Ki Baek Park (2008), "Redistributive Effects of Taxes and Transfers Including Consumption Taxes and In-kind Benefits", Research on Fiscal Studies, Vol. 56, February (in Korean).

World Bank (2008), Paying Taxes 2008; The Global Picture, Washington, D.C.

Yeo, Y., M. Kim, T. Kim, S. Yang and H. Choi (2005), An Analysis of Trends and Contributing Factors for Poverty and Inequality, Korea Institute of Health and Social Affairs, Seoul. 
ECO/WKP(2009)12

\section{Annex 1. \\ RECENT PROGRESS IN TAX REFORM IN KOREA: A FOLLOW-UP OF THE 2000 OECD ECONOMIC SURVEYS: KOREA}

The 2000 OECD Economic Surveys: Korea focused on taxation, pointing out a number of problems in the tax system and calling for comprehensive reform. Despite some progress since then, many of the problems identified in 2000 remain unresolved. The major recommendations in the 2000 Survey included:

i. $\quad$ The PIT base should be broadened by reducing allowances and credits as well as improving the taxation of fringe benefits. Tax expenditures in the PIT system rose from $0.9 \%$ of GDP in 2000 to $1.1 \%$ in 2006 , reflecting increased income deductions for the elderly and childcare. However, better coverage of the self-employed boosted the proportion paying income tax, lifting the share of direct taxes on households from 3.4\% of GDP in 2000 to $4.1 \%$ in 2006. Meanwhile, there has been little progress on taxing fringe benefits.

ii. Taxation of the self-employed should be improved. Korea has introduced a number of measures: $i$ ) incentives to use credit cards implemented in 2000 increased transparency about self-employed income; ii) the ceiling for using the "simplified" scheme for VAT was lowered from 150 million won of sales to 48 million won, thus strengthening bookkeeping obligations; iii) a cash receipt income deduction system was introduced in 2005; and $i v$ ) tax audits of high-income self-employed were increased. These measures helped raise the proportion of the self-employed paying income tax from $38 \%$ in 2000 to $63 \%$ in 2006.

iii. Personal capital income should be taxed more evenly across sources. Dividend and interest income below 40 million won ( $\$ 27000$ ) is taxed separately at a $14 \%$ rate. Above that threshold, it is subject to "global taxation" at the same rate as earned income. Meanwhile, the scope for taxexempt and tax-deductible saving instruments has been narrowed somewhat. Taxation of capital gains on real estate has been increased, while capital gains on small shareholders' stock in listed companies are still tax-exempt.

iv. The corporate tax base should be broadened by reducing and streamlining the incentives given to small and medium-sized enterprises (SMEs), $R \& D$ and overall investment. Tax expenditures for the CIT have remained around $0.7 \%$ of GDP and $20 \%$ of CIT revenue since 2000.

v. The VAT base should be broadened, in part by including agricultural products and reducing the special treatment granted to small businesses. Korea has made progress in broadening the VAT base, as reflected in the rise in its VAT Revenue Ratio from $61 \%$ in 2000 to $72 \%$ in 2005. Perhaps most important were the measures to expand the use of credit cards and to scale back the special treatment granted to small companies. However, agricultural products remain exempt from the VAT.

vi. The consumption tax structure should be simplified. The telephone tax was abolished in 2001. In addition, the number of items included in the individual consumption tax was reduced from 27 in 2000 to 20 in 2004. 
vii. The taxation of pensions should be strengthened, in part by shifting from a "TEE" system to "EET" (i.e. making employees' contributions tax deductible while taxing pension benefits) and taxing all pension income as ordinary income. Korea moved to an EET system in 2002 and this system was applied to the company pension system introduced in 2006. Pensions are taxed as ordinary income.

viii. Earmarked taxes and quasi-taxes should be abolished. While there have been some changes in earmarked taxes, they continue to play an important role, accounting for $14 \%$ of government revenue in 2007. According to the September 2008 tax reform package, the three national earmarked taxes (education, local development and transport-energy-environment) will be abolished and integrated into underlying taxes in 2010. As for quasi-taxes, they rose from $1.1 \%$ of GDP in 2000 to $1.4 \%$ in 2006.

ix. Local autonomy in the area of taxation should be strengthened. There has been little change to the local tax system. The Local Share Tax, a general grant from the central government, was raised from $15 \%$ of national internal taxes in 2000 to $19.2 \%$ in 2006 , while the role of earmarked grants was reduced.

x. $\quad$ Property taxation should be reformed by raising the tax on holdings while reducing transaction taxes and the capital gains tax in order to promote the efficient use of land. The tax on property holdings was increased by the Comprehensive Property Tax in 2005, while the registration and acquisition taxes on purchases have been reduced. In contrast, the capital gains tax has been increased for those owning more than one home.

xi. Compliance should be strengthened by increasing the number of audits and enhancing cooperation between the National Tax Service (NTS) and other government bodies, including the social security system. Although the number of tax audits has been on a downward trend, they have been more focused on high-income self-employed persons. The number of tax evaders that were prosecuted increased from 119 in 2001 to 369 in 2006. The NTS has required firms to report the payroll of non-regular workers since 2006. However, the legislation to consolidate the collection of the four social insurance contributions (pensions, health, employment and industrial accident) in one agency was rejected by the National Assembly. 


\section{WORKING PAPERS}

The full series of Economics Department Working Papers can be consulted at www.oecd.org/eco/Working_Papers/

670. Financial market stability in the European Union: Enhancing regulation and supervision (February 2009) Jeremy Lawson, Sebastian Barnes and Marte Sollie

669. Overcoming the financial crisis in the United States (February 2009) Andrea De Michelis

668. Financial crises: past lessons and policy implications (February 2009) Davide Furceri and Annabelle Mourougane

667. Reforms to open sheltered sectors to competition in Switzerland (February 2009) Andrés Fuentes

666. Raising education outcomes in Spain (February 2009) Andrés Fuentes

665. Health care reform in the United States (February 2009) David Carey, Bradley Herring and Patrick Lenain

664. The role of $R \& D$ and technology diffusion in climate change mitigation: new perspectives using the WITCH model (February 2009) Valentina Bosetti, Carlo Carraro, Romain Duval, Alessandra Sgobbi and Massimo Tavoni

663. Long-run GDP growth framework and scenarios for the world economy (January 2009) Romain Duval and Christine de la Maisonneuve

662. Realising South Africa's employment potential (January 2009) Geoff Barnard

661. Making the most of Norwegian schools (January 2009) Romina Boarini

660 Can the financial sector continue to be the main growth engine in Luxembourg? (January 2009) Arnaud Bourgain, Patrice Pieretti and Jens Høj

659. Fiscal policy responsiveness, persistence, and discretion (December 2008) António Afonso, Luca Agnello, Davide Furceri

658. The economics of climate change mitigation: policies and options for the future (December 2008) Jean-Marc Burniaux, Jean Chateau, Romain Duval and Stéphanie Jamet

657. Maximising Mexico's gains from integration in the world economy (December 2008) David Haugh, Roselyne Jamin and Bruno Rocha

656. How do taxes affect investment and productivity? An industry-level analysis of OECD countries (December 2008) Laura Vartia 
655. Strategies for countries with favourable fiscal positions

(November 2008) Robert Price, Isabelle Joumard, Christophe André and Makoto Minegishi

654. Monetary transmission mechanism in Central and Eastern Europe: Surveying the Surveable (November 2008) Balázs Égert and Ronald MacDonald

653. An Overview of the OECD ENV-Linkages Model

Jean-Marc Burniaux and Jean Château

652. Reforming the labour market in Japan to cope with increasing dualism and population ageing (November 2008) Randall S. Jones

651. Enhancing the productivity of the service sector in Japan

(November 2008) Randall S. Jones and Taesik Yoon

650. Reforming the tax system in Japan to promote fiscal sustainability and economic growth

(November 2008) Randall S. Jones and Masahiko Tsutsumi

649. What Drives the NAIRU? Evidence from a Panel of OECD Countries

(November 2008) Christian Gianella, Isabell Koske, Elena Rusticelli and Olivier Chatal

648. Short-term distributional effects of structural reforms: selected simulations in a DGSE framework (October 2008) Annabelle Mourougane and Lukas Vogel

647. Speed of adjustment to selected labour market and tax reforms

(October 2008) Annabelle Mourougane, Lukas Vogel

646. The challenge of monetary policy in Turkey

(October 2008) Olcay Çulha, Ali Çulha and Rauf Gönenç

645. Improving cost-effectiveness in the health-care sector in Iceland

(October 2008) Hannes Suppanz

644. Understanding Russian regions' economic performance during periods of decline and growth - an

Extreme Bound Analysis approach

(October 2008) Rüdiger Ahrend

643. Do tax structures affect aggregate economic growth? Empirical evidence from a panel of OECD countries

(October 2008) Jens Arnold

642. Accounting for one-off operations when assessing underlying fiscal positions

(October 2008) Isabelle Joumard, Makoto Minegishi, Christophe André, Chantal Nicq and Robert Price

641. Do corporate taxes reduce productivity and investment at the firm level? Cross-country evidence from the Amadeus dataset

(October 2008) Cyrille Schwellnus and Jens Arnold 